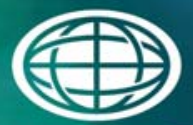

Savannah River

National Laboratory ${ }^{\mathrm{m}}$

OPERATED BY SAVANNAH RIVER NUCLEAR SOLUTIONS

\title{
WASTE TREATMENT TECHNOLOGY PROCESS DEVELOPIENT PLAN FOR HANFORD WASTE TREATMENT PLANT LOW ACTIVTY WASTE RECYCLE
}

DANIE J. MCCABE

WLUMR. WLMARTH

CHARLESA. NASH

July 2013

SRNL-STI-2013-00351, Revision 0 
SRNL-STI-2013-00351, Rev. 0

\section{DISCLAIMER}

This work was prepared under an agreement with and funded by the U.S. Government. Neither the U.S. Government or its employees, nor any of its contractors, subcontractors or their employees, makes any express or implied:

1. warranty or assumes any legal liability for the accuracy, completeness, or for the use or results of such use of any information, product, or process disclosed; or

2. representation that such use or results of such use would not infringe privately owned rights; or

3. endorsement or recommendation of any specifically identified commercial product, process, or service.

Any views and opinions of authors expressed in this work do not necessarily state or reflect those of the United States Government, or its contractors, or subcontractors.

\section{Printed in the United States of America}

Prepared for

U.S. Department of Energy 
Key Words: Technetium High Level Waste Low Activity Waste

Retention: Permanent

\title{
WASTE TREATMENT TECHNOLOGY PROCESS DEVELOPMENT PLAN FOR HANFORD WASTE TREATMENT PLANT LOW ACTIVITY WASTE RECYCLE
}

\author{
DANIEL J. MCCABE \\ WILLIAM R. WILMARTH \\ CHARLES A. NASH
}

July, 2013

Prepared for the U.S. Department of Energy under contract number DE-AC09-08SR22470.

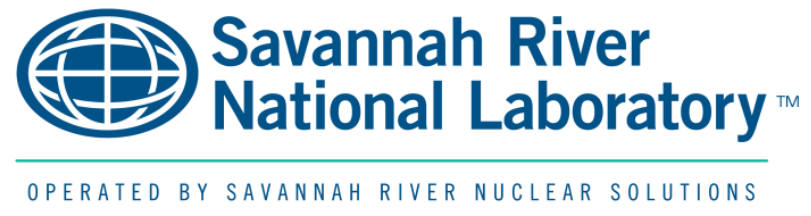




\section{REVIEWS AND APPROVALS}

\section{AUTHORS:}

Daniel J. McCabe, SRNL Advanced Characterization and Process Research

Date

William R. Wilmarth,

Date

SRNL Environmental \& Chemical Process Technology Research Programs

Charles A. Nash, SRNL Advanced Characterization and Process Research

Date

TECHNICAL REVIEW: (Reviewed Per E7, 2.60)

David Hobbs, Peer Review, SRNL Advanced Characterization and Process Research $\quad$ Date

\section{APPROVAL:}

Frank Pennebaker, SRNL Manager

Date

Advanced Characterization and Process Research

Connie Herman, SRNL Hanford Programs Manager

Date

Environmental \& Chemical Process Technology Research Programs

Sharon Marra, SRNL Manager

Date

Environmental \& Chemical Process Technology Research Programs 
SRNL-STI-2013-00351, Rev. 0

\section{EXECUTIVE SUMMARY}

The purpose of this Process Development Plan is to summarize the objectives and plans for the technology development activities for an alternative path for disposition of the recycle stream that will be generated in the Hanford Waste Treatment Plant Low Activity Waste (LAW) vitrification facility (LAW Recycle). This plan covers the first phase of the development activities. The baseline plan for disposition of this stream is to recycle it to the WTP Pretreatment Facility, where it will be concentrated by evaporation and returned to the LAW vitrification facility. Because this stream contains components that are volatile at melter temperatures and are also problematic for the glass waste form, they accumulate in the Recycle stream, exacerbating their impact on the number of LAW glass containers. Approximately $32 \%$ of the sodium in Supplemental LAW comes from glass formers used to make the extra glass to dilute the halides to acceptable concentrations in the LAW glass, and reducing the halides in the Recycle is a key component of this work. Additionally, under possible scenarios where the LAW vitrification facility commences operation prior to the WTP Pretreatment facility, this stream does not have a proven disposition path, and resolving this gap becomes vitally important. This task seeks to examine the impact of potential future disposition of this stream in the Hanford tank farms, and to develop a process that will remove radionuclides from this stream and allow its diversion to another disposition path, greatly decreasing the LAW vitrification mission duration and quantity of glass waste.

The origin of this LAW Recycle stream will be from the Submerged Bed Scrubber (SBS) and the Wet Electrostatic Precipitator (WESP) from the LAW melter off-gas system. The stream is expected to be a dilute salt solution with near neutral $\mathrm{pH}$, and will likely contain some insoluble solids from melter carryover or precipitates of scrubbed components (e.g. carbonates). The soluble components are mostly sodium and ammonium salts of nitrate, chloride, and fluoride. This stream has not been generated yet, and will not be available until the WTP begins operation, causing uncertainty in its composition, particularly the radionuclide content. This plan will provide an estimate of the likely composition and the basis for it, assess likely treatment technologies, identify potential disposition paths, establish target treatment limits, and recommend the testing needed to show feasibility. Two primary disposition options are proposed for investigation, one is concentration for storage in the tank farms, and the other is treatment prior to disposition in the Effluent Treatment Facility.

One of the radionuclides that is volatile and expected to be in high concentration in this LAW Recycle stream is Technetium-99 ( $\left.{ }^{99} \mathrm{Tc}\right)$, a long-lived radionuclide with a half-life of 210,000 years. Technetium will not be removed from the aqueous waste in the Hanford Waste Treatment and Immobilization Plant (WTP), and will primarily end up immobilized in the LAW glass, which will be disposed in the Integrated Disposal Facility (IDF). Because ${ }^{99}$ Tc has a very long half-life and is highly mobile, it is the largest dose contributor to the Performance Assessment (PA) of the IDF. Other radionuclides that are also expected to be in appreciable concentration in the LAW Recycle are ${ }^{129} \mathrm{I},{ }^{90} \mathrm{Sr},{ }^{137} \mathrm{Cs}$, and ${ }^{241} \mathrm{Am}$. The concentrations of these radionuclides in this stream will be much lower than in the LAW, but they will still be higher than limits for some of the other disposition pathways currently available. 
Although the baseline process will recycle this stream to the Pretreatment Facility, if the LAW facility begins operation first, this stream will not have a disposition path internal to WTP. One potential solution is to return the stream to the tank farms where it can be evaporated in the 242A evaporator, or perhaps deploy an auxiliary evaporator to concentrate it prior to return to the tank farms. In either case, testing is needed to evaluate if this stream is compatible with the evaporator and the other wastes in the tank farm. It should be noted that prior experience in evaporation of another melter off-gas stream, the Recycle Stream at the SRS Defense Waste Processing Facility, unexpectedly caused deleterious impacts on evaporator scaling and formation of aluminosilicate solids before controls were implemented.

The compatibility of this stream with other wastes and components in the tank farms has not been fully investigated, whether it is sent for storage in AW-102 in preparation for evaporation in 242-A evaporator, or if it is pre-concentrated in an auxiliary evaporator. This stream is expected to be unusual because it will be very high in corrosive species that are volatile in the melter (chloride, fluoride, sulfur), will have high ammonia, and will contain carryover particulates of glass-former chemicals. These species have potential to cause corrosion, precipitation, flammable gases, and scale in the tank farm system. Testing is needed to demonstrate acceptable conditions and limits for these compounds in wastes sent to the tank farms.

Alternate disposition of this LAW Recycle stream could beneficially impact WTP, and may also remove a sizeable fraction of the ${ }^{99} \mathrm{Tc}$ from the source term at the IDF. The alternative radionuclide removal process envisioned for this stream parallels the Actinide Removal Process that has been successfully used at SRS for several years. In that process, Monosodium Titanate (MST) is added to the tank waste to adsorb ${ }^{90} \mathrm{Sr}$ and actinides, and then the MST and radionuclides are removed by filtration. The process proposed for investigation for the Hanford WTP LAW Recycle stream would similarly add MST to remove ${ }^{90} \mathrm{Sr}$ and actinides, along with other absorbents or precipitating agents for the remaining radionuclides. These include inorganic reducing agents for Tc, and zeolites for ${ }^{137} \mathrm{Cs}$. After treatment, disposition of the decontaminated Recycle stream may be suitable for the Effluent Treatment Facility, where it could be evaporated and solidified. The contaminated slurry stream containing the absorbents and radionuclides will be preliminarily characterized in this phase of the program to evaluate disposal options, and disposition routes will be tested in the next phase. The testing described herein will aid in selection of the best disposal pathway.

Several research tasks have been identified that are needed for this initial phase:

- Simulant formulation

- Concentration of Recycle to reduce storage volume

- Blending of concentrated Recycle with tank waste

- Sorption of radionuclides

- Precipitation of radionuclides

After this initial phase of testing, additional tasks are expected to be identified for development. These tasks likely include evaluation and testing of applicable solid-liquid separation technologies, slurry rheology measurements, composition variability testing and evaluations, corrosion and erosion testing, slurry storage and immobilization investigations, and decontaminated Recycle evaporation and solidification. 
Although there are a number of unknown parameters listed in the technical details of the concepts described here, many of these parameters have precedence and do not generally require fundamental new scientific breakthroughs. Many of the materials and processes described are already used in radioactive applications in the DOE complex, or have been tested previously in comparable conditions. Some of these materials and equipment are already used in High Level Waste applications, which are much more complex and aggressive conditions than the LAW Recycle stream. In some cases, the unknown parameters are simply extensions of already studied conditions, such as tank waste corrosion chemistry. The list of testing needs at first appears daunting, but virtually all have been done before, although there are potential issues with compatibility with this unique waste stream. It is anticipated that the challenge will be more in integrating the system and complying with process limitations than in developing entirely new technologies.

Several assumptions have been made in this document about the acceptability of radionuclide decontamination and potential waste forms for disposal. These assumptions have been used to define acceptability criteria for feasibility studies on removal. These limits are not intended to define regulatory or facility limits, but rather provide a starting point for evaluating various technologies.

Table 1 Summary of Tasks

\begin{tabular}{|c|c|c|}
\hline Task & Phase 1 Scope & Phase 2 Scope \\
\hline Simulant Formulation & $\begin{array}{l}\text { Coupled operations process } \\
\text { average }\end{array}$ & Composition Variability Studies \\
\hline Blending & $\begin{array}{l}\text { Concentrated LAW Recycle } \\
\text { simulant blending tests with } \\
\text { AW-101 simulant }\end{array}$ & $\begin{array}{l}\text { Compatibility assessment } \\
\text { calculations } \\
\text { LERF compatibility }\end{array}$ \\
\hline Ion Exchange/Adsorption & $\begin{array}{l}\text { Scoping tests: } \\
\text { Tc (if precipitation fails) } \\
\text { Actinides } \\
\text { Sr } \\
\text { Cs } \\
\text { Iodine evaluation }\end{array}$ & $\begin{array}{l}\text { Optimization tests: } \\
\text { Tc } \\
\text { Actinides } \\
\text { Sr } \\
\text { Cs } \\
\text { Iodine (if needed) }\end{array}$ \\
\hline Precipitation & $\begin{array}{l}\text { Scoping tests: } \\
\text { Tc }\end{array}$ & $\begin{array}{l}\text { Solid-liquid separation } \\
\text { Optimization tests: } \\
\text { Tc } \\
\text { Slurry properties }\end{array}$ \\
\hline Concentration & $\begin{array}{l}\text { Evaporation with lab equipment } \\
\text { Solids characterization } \\
\text { Reverse Osmosis evaluation } \\
\text { (potential non-radioactive } \\
\text { testing) }\end{array}$ & $\begin{array}{l}\text { Evaporation with scaled mock- } \\
\text { up lab equipment } \\
\text { Solids characterization and scale } \\
\text { formation } \\
\text { Reverse Osmosis DF testing } \\
\text { Prefiltration methods } \\
\text { Corrosion }\end{array}$ \\
\hline
\end{tabular}




\section{TABLE OF CONTENTS}

LIST OF FIGURES vii

LIST OF ACRONYMS viii

1.0 INTRODUCTION $\quad 1$

1.1 Simulant Formulation Basis $\quad 1$

1.2 Concentration Methods $\quad 4$

1.3 Alternative Disposition Of Law Recycle $\quad 5$

$\begin{array}{ll}1.4 \text { Additional Waste Streams } & 9\end{array}$

1.5 Process Integration $\quad 9$

2.0 TECHNOLOGY DEVELOPMENT 10

2.1 Simulant Formulation $\quad 10$

2.2 Law Recycle Simulant Blending $\quad 11$

2.3 Ion Exchange/Adsorption $\quad 12$

2.3.1 Technetium 13

2.3.2 Actinides $\quad 13$

2.3.3 Strontium 13

2.3.4 $\underline{\text { Cesium }} 13$

2.3.5 Iodine $\quad 14$

2.4 Precipitation $\quad 14$

2.5 Concentration $\quad 14$

3.0 CONCLUSIONS $\quad 15$

$\begin{array}{ll}\text { 4.0 REFERENCES } & 17\end{array}$

$\begin{array}{ll}5.0 \text { ATTACHMENTS } & 19\end{array}$

Appendix A. SBS/WESP LAW Composition and DF Calculation Results A-1 


\section{LIST OF FIGURES}

Figure 1 Simplified LAW Off-gas System 2

Figure 2 Schematic of Disposition of LAW Recycle to Tank Farms 3

Figure 3 Schematic of Alternative Concentration of LAW Recycle 3

Figure 4 Schematic of Alternative Disposition of LAW Recycle 4

\section{LIST OF TABLES}

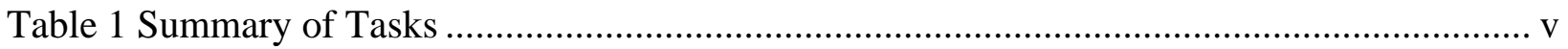




\section{LIST OF ACRONYMS}

$\begin{array}{ll}\text { ARP } & \text { Actinide Removal Process (at SRS) } \\ \text { BFS } & \text { Blast Furnace Slag } \\ \text { Ci } & \text { Curie } \\ \text { CFR } & \text { Code of Federal Regulations } \\ \text { CST } & \text { Crystalline Silicotitanate } \\ \text { DF } & \text { Decontamination Factor } \\ \text { DOE } & \text { Department of Energy } \\ \text { DST } & \text { Double Shell Tank (HLW storage) } \\ \text { ETF } & \text { Effluent Treatment Facility } \\ \text { HEPA } & \text { High Efficiency Particulate Air (filters) } \\ \text { HLW } & \text { High Level Waste } \\ \text { HTWOS } & \text { Hanford Tank Waste Operations Simulator } \\ \text { IDF } & \text { Integrated Disposal Facility } \\ \text { ILAW } & \text { Immobilized Low Activity Waste } \\ \text { IX } & \text { Ion Exchange } \\ \text { L } & \text { Liter } \\ \text { LAW } & \text { Low Activity Waste } \\ \text { LERF } & \text { Liquid Effluent Retention Facility } \\ \text { MST } & \text { Monosodium Titanate } \\ \text { mMST } & \text { modified Monosodium Titanate } \\ \text { ORP } & \text { Office of River Protection (DOE) } \\ \text { PA } & \text { Performance Assessment } \\ \text { PTT } & \text { Primary Treatment Train (at ETF) } \\ \text { RCRA } & \text { Resource Conservation and Recovery Act } \\ \text { RO } & \text { Reverse Osmosis } \\ \text { SALDS } & \text { State Approved Land Disposal Site (ETF discharge) } \\ \text { SBS } & \text { Submerged Bed Scrubber } \\ \text { SRS } & \text { Savannah River Site } \\ \text { STT } & \text { Secondary Treatment Train (at ETF) } \\ \text { STU } & \text { Solidification Treatment Unit (at ETF) } \\ \text { SWRT } & \text { Secondary Waste Receiver Tanks (at ETF) } \\ \text { TRU } & \text { Trans-Uranic } \\ \text { WESP } & \text { Wet Electrostatic Precipitator } \\ \text { WTP } & \text { Waste Treatment Plant } \\ & \end{array}$




\subsection{INTRODUCTION}

The Hanford LAW Recycle stream will be generated in the WTP by condensation and scrubbing of the LAW melter off-gas system by a SBS and WESP, as shown in Figure 1. This stream, which will contain substantial amounts of chloride, fluoride, ammonia, and sulfate ions, will get recycled within the WTP process. The halide and sulfate components are only marginally soluble in glass, and often dictate the waste loading. Additionally, long-lived ${ }^{99} \mathrm{Tc}$ and ${ }^{129} \mathrm{I}$ are volatile radionuclides that accumulate in the LAW system, and are challenging to incorporate in glass under the Hanford LAW melter operating conditions. Because ${ }^{99}$ Tc has a very long half-life and is highly mobile, it is the largest dose contributor to the Performance Assessment (PA) of the IDF [Mann, 2008]. Diverting this LAW Recycle stream to an alternate disposal path would have substantial beneficial impacts on the cost, life cycle, and operational complexity of WTP. The objective of this process development task is to evaluate technical compatibility and options for disposition of the Hanford LAW Recycle stream in the Tank Farms (Figures 2 and 3) should the LAW facility commence operations prior to operation of the Pretreatment facility, and to identify and demonstrate a radionuclide separation step for a plausible alternative disposition path (Figure 4) during the entire duration of WTP operations.

The purpose of this plan is to select and describe the technical elements of testing needed to evaluate concentration and blending of the stream in the tank farms, document the assumptions and basis for decisions, and describe a possible alternative radionuclide removal process and plans for testing the alternative to enable decision-making. This plan will detail the steps necessary for developing the technology to the point where its feasibility can be assessed and then evaluate what it would take to ready it for project insertion. Because this stream is not yet available for characterization, this plan will also describe the basis for how the simulant will be formulated.

This plan is described in the Task Technical and Quality Assurance Plan for Developing a Flowsheet for Off-Gas Process Liquids from the Hanford Low Activity Waste Vitrification Process [Wilmarth, 2013].

\subsection{Simulant Formulation Basis}

The simulant formulation will be based on two inputs. The solution chemistry and radionuclide content will be based on version 7.4 of the Hanford Tank Waste Operations Simulator (HTWOS) modeling of the flow sheet [Belsher, 2012]. The insoluble solids composition will be primarily based on analysis of LAW Recycle obtained from pilot-scale simulant melter testing. Basing the solution chemistry and radionuclide content on the computer modeling rather than melter testing results allows evaluation of all process conditions for treatment of all wastes, and includes internal WTP process streams. Since the model does not account for carryover of glass formers, the insoluble solids (which appear to be largely glass-formers) will be based on results from pilot-scale melter off-gas system testing. After collating all of this information, the individual components will be further assessed by comparisons between the measured and computed values, and adjustments may be made, based on scientific judgment. Further, the composition will be evaluated using chemical thermodynamic modeling software to determine potential 


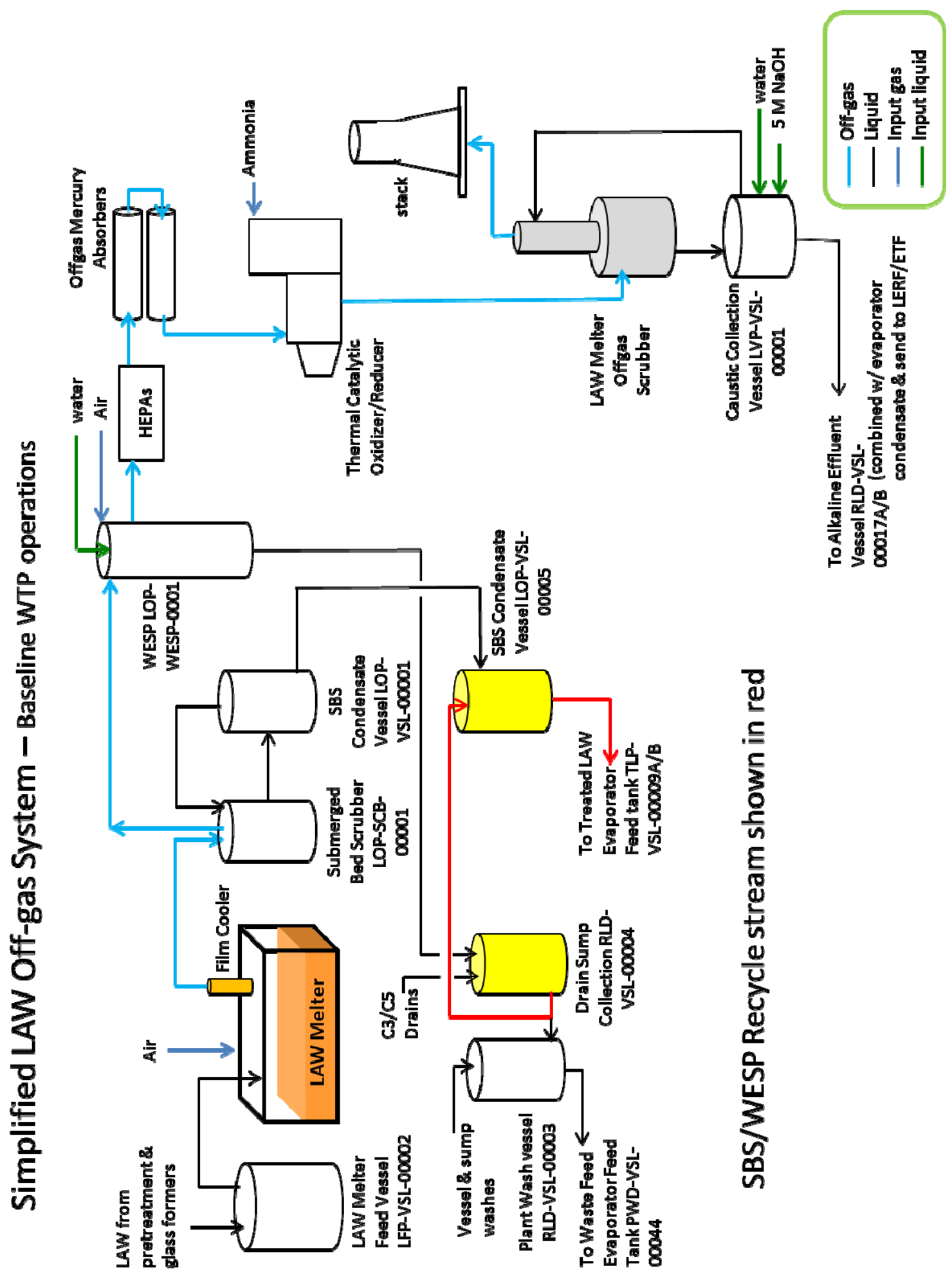

Figure 1 Simplified LAW Off-gas System

(adapted from 24590-WTP-RPT-PT-02-005, Rev. 6); (yellow indicates SBS/WESP LAW Recycle collection tanks) 


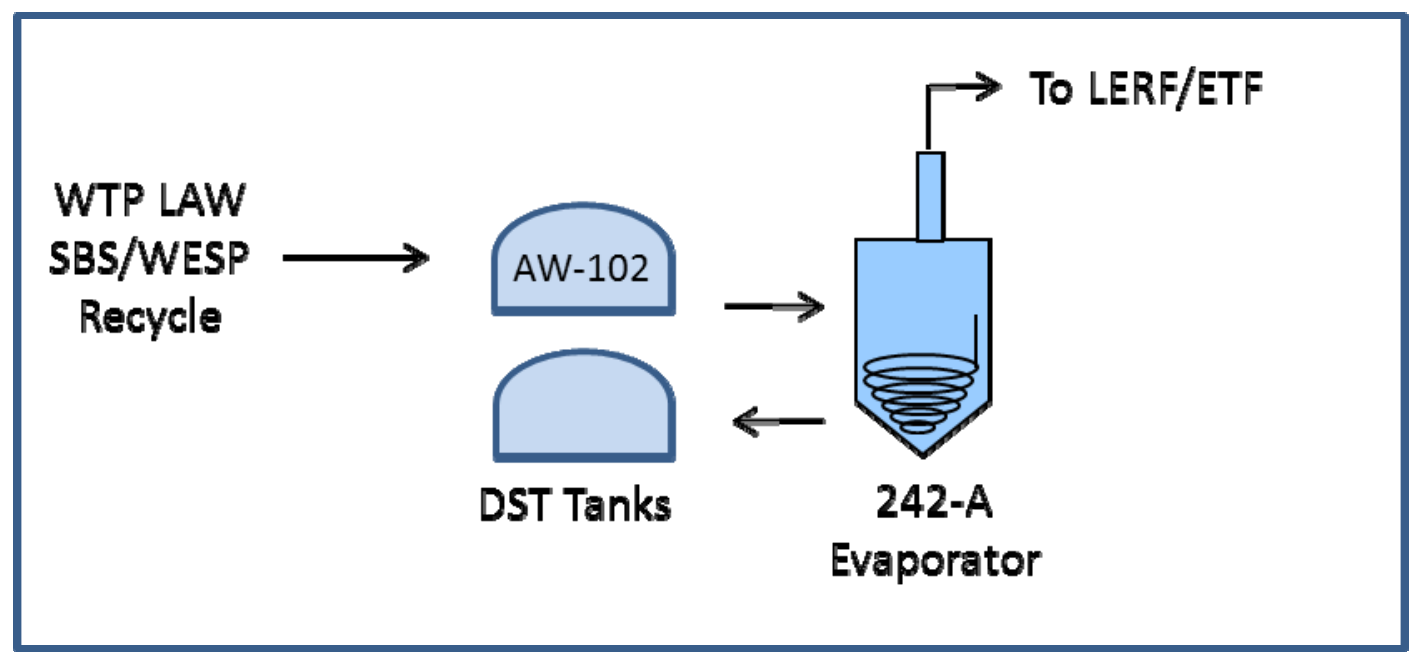

Figure 2 Schematic of Disposition of LAW Recycle to Tank Farms

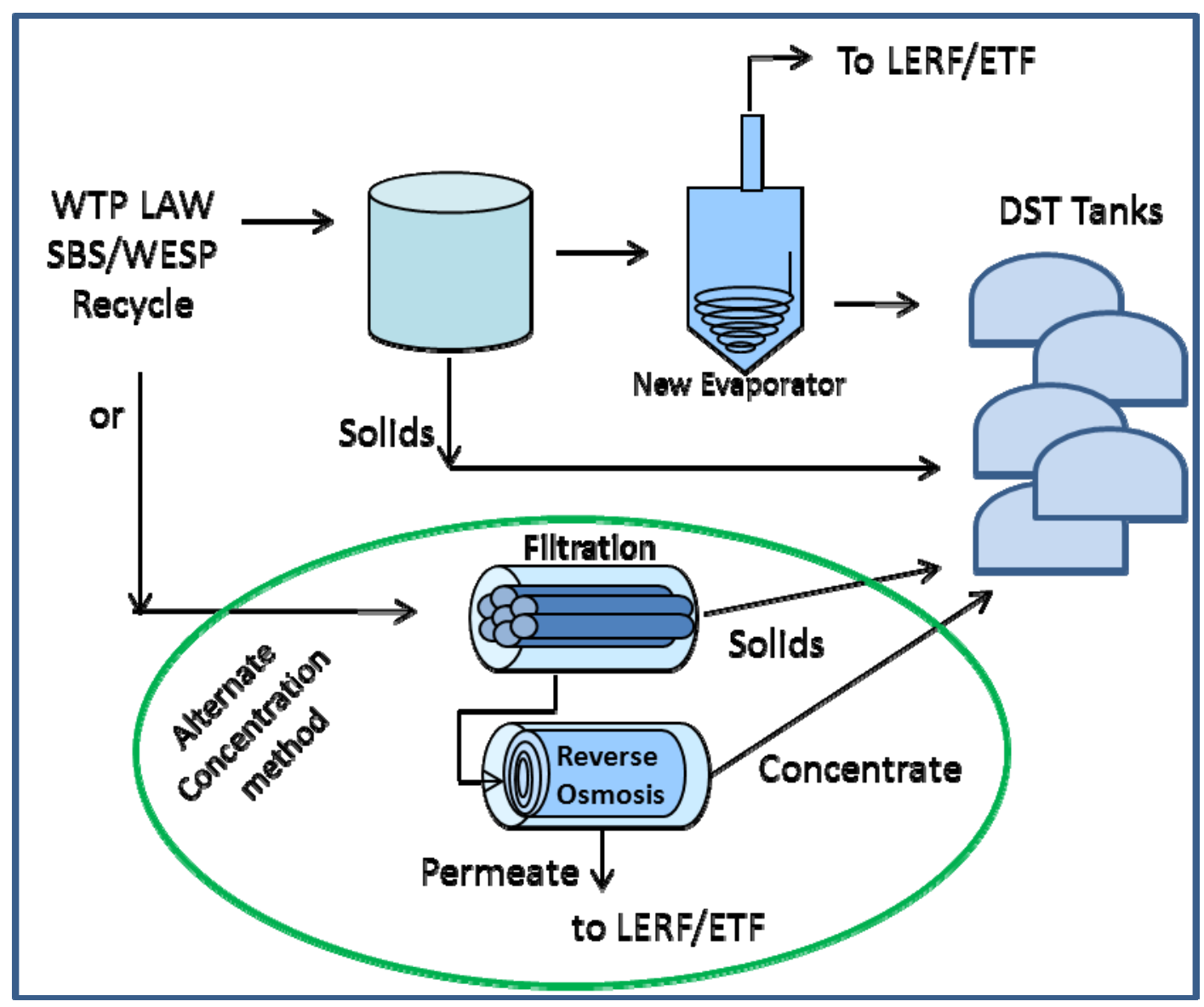

Figure 3 Schematic of Alternative Concentration of LAW Recycle 


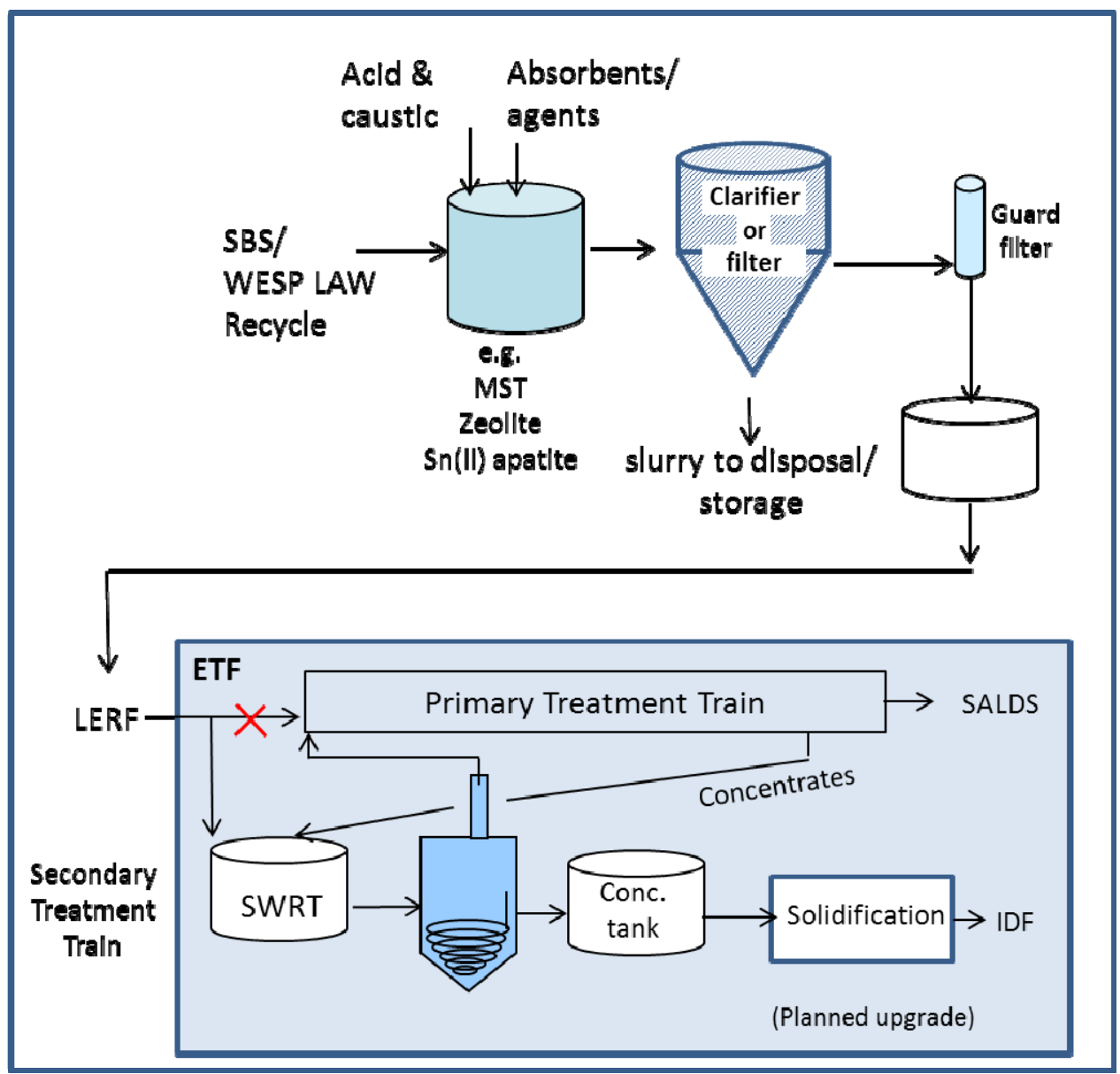

\section{Figure 4 Schematic of Alternative Disposition of LAW Recycle}

(by decontamination and processing in ETF)

formation of insoluble solids, and dissolution of glass-former solids. Ultimately, laboratory testing will dictate the final, actual composition. In later phases of this program, variability in composition will be evaluated ${ }^{1}$. The scenario selected as the basis for the solution chemistry for the HTWOS model run will be full operation of all of the WTP facilities, including second LAW melters, but with diversion of the LAW Recycle streams out of the LAW melter facilities. This has the effect of lowering the concentration of volatile species (versus the condition where it is recycled and they accumulate), but is more realistic of the condition that would be encountered in any of the proposed disposition pathways.

\subsection{Concentration Methods}

If the LAW Facility starts up first, concentration of this waste stream may be needed to accommodate its storage in the Tank Farms [Crawford, 2008]. This is because the WTP will produce more aqueous waste volume than it treats, albeit with much lower activity and ionic strength, and there may be insufficient storage capacity for it, depending on several factors.

\footnotetext{
${ }^{1}$ In this document, program phases are defined as technical scope to define the concept, not by budget or fiscal year.
} 
Concentration methods that will be evaluated are evaporation and reverse osmosis (RO). Evaporation generally has the advantage of very high decontamination and concentration factors, but is energy intensive. RO has the advantage of compact equipment and minimal energy input, but with lower decontamination and concentration factors. Both evaporation and RO have long histories of successful operation on dilute, low-activity waste streams at both SRS and Hanford. However, fouling and scaling can occur in both technologies depending on the waste composition.

Using an evaporator for this concentration step has been discussed [Crawford, 2008, Yanochko, 2012], but not a Reverse Osmosis unit. For this task it is assumed that evaporation in the 242-A evaporator would require first sending the Recycle to the Double Shell Tank (DST) system for storage, whereas, using an alternate evaporator or RO would not require interim storage. In either case, prior to putting any stream into a High Level Waste (HLW) storage tank, it is expected that caustic and nitrite will be added to comply with tank corrosion chemistry requirements. Evaporator testing will examine these two scenarios: (1) where the LAW Recycle, including insoluble solids, is first adjusted for corrosion control and then stored prior to evaporation; and (2) where the LAW Recycle is decanted from the insoluble solids, evaporated, and then adjusted for corrosion. These scenarios are consistent with anticipated conditions for evaporation in 242-A and an auxiliary evaporator, respectively.

Additional corrosion control limits may ultimately be imposed on this waste stream because of the high halide and sulfate content. Examination of the adequacy of current corrosion limits for disposition of this unique waste stream in the tank farms will be performed in the next phase of this program, if this is identified as the preferred disposition path. Regardless of the corrosion concerns, the unusual chemistry of this Recycle stream may cause formation of intractable solids when blended with some tank wastes.

The concentration of this stream by evaporation and RO, and the blending with tank wastes will be evaluated in this task. Another potential source of intractable solids formation in the HLW tanks is the silica in the insoluble solids in the LAW Recycle stream. This potential impact of the insoluble solids in the LAW Recycle stream on the formation of aluminosilicates in the HLW storage tanks will be evaluated in the next phase of testing.

\subsection{Alternative Disposition Of Law Recycle}

Disposition of the Recycle stream in an alternate pathway would have substantial long-term benefits for the Hanford WTP mission by avoiding accumulation of the volatile components that impact Immobilized LAW (ILAW) glass volume. The fluoride, sulfate, and chloride content often limits the LAW glass waste loading, dictating generation of additional glass containers [Yanochko, 2012]. Regardless of whether the LAW facility begins operation first, decoupling the Recycle stream from the Pretreatment Facility operation will enable realizing the benefit of an alternate disposal path.

The Supplemental LAW Facility produces more glass for a given amount of feed than does the WTP ILAW. This is a result of recycling the Supplemental LAW Facility's submerged bed scrubbers (SBS) and WESP back into the Supplemental LAW feed which causes halides (chlorine and fluorine) and to a lesser extent sulfur (mostly as sulfates) to buildup in the feed. 
Approximately $32 \%$ of the sodium in the Supplemental LAW Facility comes from glass formers used to make the extra glass to dilute halides to acceptable concentrations in ILAW..." [Arakali, 2012].

One option that has been previously evaluated is disposal of the LAW Recycle stream directly to the ETF. This option has a number of consequences to ETF including increases in waste volume, halide levels and radioactivity [Lueck, 2008; May, 2009]. Some of these consequences would be mitigated by first decontaminating the stream, as proposed here. Routing this stream to ETF may increase the volume of waste to be treated at ETF, and will change its composition and treatment requirements. Sending this stream to ETF may increase the volume versus the baseline because although the baseline plans for the WTP Pretreatment Facility call for evaporating this stream, some of the condensate is reused internally for processing. Only the condensate that is not needed within the process (for uses such as sludge washing, ion exchange resin rinsing, etc.) will be sent to ETF. Since this evaporator condensate would not be reused internally, the overall volume to ETF may increase. The amount of halide sent to ETF will increase substantially, which is expected to impact corrosion [Lueck, 2008]. Likewise, the radionuclide content would substantially increase, and would challenge existing treatment capabilities [May, 2009]. If the radionuclides are removed from the Recycle stream in an alternate process and the decontaminated liquid is then sent to the ETF (Figure 3), the fluoride, sulfate, and chloride would be purged from the LAW system, yielding substantial benefits to WTP and mitigating the consequences of radioactive contamination, but impacting ETF. A more detailed evaluation of the impact on the ETF and Solidification Treatment Unit (STU) throughput will be performed in the next phase of the program, after waste stream compositions and radionuclide contents are better defined.

The only chemical form of ${ }^{99}$ Tc expected in the LAW melter Recycle stream is as pertechnetate anion $\left(\mathrm{TcO}_{4}{ }^{-}\right)$with a +7 technetium oxidation state. Although some ${ }^{99} \mathrm{Tc}$ is present in the initial LAW stream as a soluble "non-pertechnetate" species, the LAW melter is expected to convert it to the same volatile species formed by vitrifying the pertechnetate, which is expected to dissociate to pertechnetate ion when it contacts the water in the SBS and WESP. Note that the dissociation of the volatilized technetium species upon contact with water in the SBS and WESP has not been demonstrated.

The current WTP baseline assumption is that technetium will not be removed from the aqueous waste in the Hanford waste treatment plant, and will primarily end up immobilized in the LAW glass waste form after several recycle passes to improve retention [Abramowitz, 2012]. The LAW glass will be disposed in the IDF. Because ${ }^{99}$ Tc has a very long half-life and is highly mobile [Icenhower, 2008, 2010], it is the major dose contributor to the PA of the IDF [Mann, 2003], even though it is largely retained by the glass. Due to the high water solubility, high volatility during vitrification, and potential for impact to the PA, effective management of ${ }^{99}$ Tc is important to the overall success of the River Protection Project mission. If a process was implemented that allowed disposal of the radionuclides offsite (e.g. by incorporation into HLW glass instead), the amount of ${ }^{99}$ Tc disposed in LAW glass at the IDF would decrease substantially. 
Other radionuclides have either volatile forms (e.g. $\left.{ }^{129} \mathrm{I}\right)$ or are carried over as particulates from the melter into the off-gas system, or some combination of both mechanisms. The estimated level of activity and soluble salts in the Recycle stream is expected to generally exceed that in the routine streams (evaporator concentrate and groundwater) currently processed at the ETF [Lueck, 2008].

For this proposed alternative treatment process, separation of the radionuclides will be done by precipitation or sorption on engineered materials and settling and/or filtration, similar to the SRS Actinide Removal Facility. For the Recycle stream, several sorbents and precipitating agents will be selected for testing. Emphasis will be on using entirely inorganic materials to enable easier storage and disposal as immobilized waste. For technetium removal, these materials will include reducing agents (e.g. Sn(II) or Fe(II) compounds) coupled with absorbents (e.g. hydroxyapatite). For cesium removal, the primary material tested will be zeolites. Because of the low ionic-strength and near-neutral $\mathrm{pH}$, zeolites are feasible agents for separation of cesium, although ammonium ions may interfere. The strontium, lanthanides, and actinides, could be removed with monosodium titanate (MST) used at SRS ARP. Additional testing may be performed with modified MST (mMST) to improve the adsorption kinetics.

For this proposed alternative treatment process, this plan will assume that the aqueous decontaminated Recycle stream will be routed to the Liquid Effluent Retention Facility (LERF), which consists of three 7.8-million gallon lined, covered basins. Although not currently practiced, it is assumed that the Recycle will be segregated from the other waste streams into one of the three basins. The Recycle will then be transferred into the Secondary Waste Receiver Tanks (SWRT) in the ETF Secondary Treatment Train (STT), and not to the Primary Treatment Train (PTT) containing the RO system (similar to case 2 in [May, 2009]).

From the SWRT, the stream will be fed to the evaporator feed tank. This segregation will enable receipt of the much higher ionic-strength Recycle stream without impacting the PTT. It is assumed here that the evaporator bottoms will be immobilized in the yet-to-be-built STU, and disposed in the IDF. The evaporator condensate will be assumed to be treated in the PTT at ETF, as current practice, to enable further decontamination and subsequent discharge through the State Approved Land Disposal Site (SALDS).

It is expected that the combined decontamination factors of the evaporator and the PTT will not cause exceeding the facility discharge permit limit, since this is essentially the baseline, with evaporation in WTP instead, prior to discharging to the ETF PTT. Therefore, the allowable amount of radionuclides in the stream to ETF will be driven by the dose rates in the LERF and ETF, and the disposal requirements for the evaporator bottoms as solidified waste in IDF. Key requirements for the disposed solid waste [May, 2009] included in this plan are: (1) Transuranic content $<100 \mathrm{nCi} / \mathrm{g}$ per DOE O 435.1 Radioactive Waste Management; and (2) radiological contaminant levels shall not exceed Class C low level waste per 10 CFR 65.11 Waste Classification. These requirements, along with ETF design shielding limits and LERF bounding source term limits, will be used to calculate the decontamination factor requirements for accepting the Recycle stream at ETF. 
Ultimately, disposition of the solidified waste in IDF would likely require a Performance Assessment calculation. In the absence of such a calculation, constituents that are in appreciable quantities will also be removed by the currently available technology to the extent practical. Rather than establishing a target DF based on regulations or limits, the achievable DF will be measured using practical amounts of adsorbents or precipitating agents. There is also an assumed source term for radionuclides in the STU waste form sent to the IDF used for the PA calculations. While this is not a defined limit, the achievable DF will target a low radionuclide content to minimize the potential impact. This can then be compared with the values used for the PA calculations to determine if the process is feasible. Other factors and limits may be uncovered as the testing progresses, such as the fate of ${ }^{129} \mathrm{I}$, and these will be addressed in the next phase of the program, if necessary. Other solid waste disposal requirements, such as RCRA compliance, will be assumed achievable with modification of the STU solidification process and will be addressed in the subsequent phases of this program. Regulatory permitting is outside the scope of this task.

Hardware modifications will be needed at the ETF to accommodate this Recycle treatment scheme [Lueck, 2008]. The routing of the stream from the LERF directly to the evaporator feed tank (Secondary Waste Receipt Tanks) will require piping changes. Additionally, the material of construction of the Secondary Treatment Train, including the tanks, equipment, and piping, are not compatible with high halide and sulfate wastes. These components are assumed to be upgraded as previously evaluated to allow evaporation of wastes to halide concentrations of up to 40,000 ppm [Edgemon, 2012], but this has not been fully vetted. The ETF corrosion mitigation upgrades and costs are assumed to be identical to those already described for Case 2 in RPPRPT-43588, Rev. 0 [May, 2009].

The location for this proposed alternative treatment process is assumed to be in close proximity to the Hanford WTP, likely in an adjoining building. This would minimize the distance for pumping the slurry containing the radionuclides and minimize changes to the transfer lines to the LERF. The process is envisioned to be very similar to the equipment used for the SRS ARP, and can utilize designs and lessons learned from that process. The solid-liquid separation equipment may include a clarifier prior to filtration to reduce the burden on the filter and maximize throughput, but that will be determined in a later phase of this program.

The adsorbent/precipitate slurry containing the radionuclides will be characterized, and its potential disposition pathways will be evaluated. Since the primary adsorbents and precipitating agents under investigation are inorganic, they should be compatible with the widest range of disposal options. They can also be evaluated for mixing as a slurry with the tank waste sludges, since inorganic materials can be accommodated more easily than organic materials in the tank farms, if interim storage is needed. Immobilization testing will be in a subsequent phase of this program, once the slurry composition and quantities are defined.

The information generated in this task will include estimates of process parameters such as sludge/absorbent volume, reaction kinetics, and achievable DF, for selection of a path forward. These estimates will include radionuclide removal kinetics to aid in equipment sizing projections, adsorbent/precipitant generation rates that will allow estimates of secondary waste volumes and material costs, and preliminary decontamination factors to judge the ability to 
remove radionuclides to an acceptable level. Subsequent phases of this program will examine more details and optimization of the parameters.

\subsection{Additional Waste Streams}

It should be noted that there is another aqueous stream from the LAW melter vitrification off-gas system that is generated in the caustic scrubber. This stream is generated after the off-gas has passed the HEPA filters, so is essentially non-radiological. In fully coupled operations of the WTP, this stream is returned to the Pretreatment Facility, blended with evaporator condensate, and sent to ETF. For this task, it is assumed that this stream is sent directly to the ETF and is not mixed with the LAW Recycle. Because of the piping configuration, this may not be practical, and may end up being sent to the same LERF basin as the LAW Recycle. If so, the next phase of testing will address whether any precipitates would form in the LERF, or if there are other downstream consequences. Similarly, there is a plant wash vessel that collects periodic streams that will be evaluated for inclusion in the processes.

\subsection{Process Integration}

This evaluation focuses on the options for disposition of the LAW Recycle stream. During normal WTP operations, this stream is recycled into the Pretreatment Facility, where it is evaporated and the concentrate is mixed with "freshly treated" LAW and returned to the LAW melter. Since the entire process is integrated, the freshly treated LAW also contains process liquids from miscellaneous systems, such as the SBS/WESP from the HLW melter and leachate from HLW sludge leaching. Therefore, the LAW Recycle stream composition is dependent not only on the tank waste being processed, but also on the operation and status of the HLW and Pretreatment facilities. In particular, any volatile components from the HLW melter will be captured in the HLW SBS and WESP stream, which will be blended in the Pretreatment facility with filtered tank waste and evaporated and filtered. If those components are soluble, they will be processed through cesium ion exchange and then cycled into the LAW melter, ultimately affecting the LAW Recycle stream composition. Since in normal operations the LAW Recycle is recycled into the LAW melter yet again, the volatile components can build up appreciably. In addition to variability in the tank waste composition, the composition of LAW will also depend on the status of the pretreatment process. For example, when sludge leaching is being performed, the waste being sent to LAW will have lower nitrate and halides and higher caustic and aluminum or chromium, affecting the chemistry of the LAW Recycle stream.

Since the composition of the LAW Recycle, particularly of the volatile components, will depend on several factors, it is challenging to select the bounding condition for testing of a stream in a facility that is not yet operational. Because the volatile components from the HLW melter will end up in the LAW melter Recycle stream, the composition derived from fully coupled operations would have more problematic components than the non-coupled case; i.e., more Tc, actinides, $\mathrm{Cl}$, and $\mathrm{F}$ would be expected in LAW Recycle during fully coupled operations. Therefore, the basis for this testing will utilize the composition projected from fully coupled operations, including second LAW melters, but with the LAW Recycle diverted from the facilities. However, this would not actually be the situation for the scenario where the LAW Recycle is returned to the tank farms. That scenario would only be realized if only the LAW facility was operating, because the baseline case recycles the stream if the HLW and 
Pretreatment Facilities are operating. Regardless, this conservative realistic case would be to use the composition of the LAW Recycle that is derived from fully coupled operations and diverted LAW Recycle, since it would have the highest composition of problematic components, but would not cause excess accumulation of components within the LAW melter systems. This phase of this task will therefore utilize a simulant formulation derived from fully coupled operations and diversion of the LAW Recycle out of the LAW melter facilities. It is expected that many of the volatile species from the HLW melter end up in the LAW feed due to the internal recycle of HLW SBS/WESP scrubber solution within the Pretreatment facility. To check on the validity of this condition, an HTWOS model run of fully coupled operations will be examined to quantify the impact of HLW Recycle on the LAW melter feed composition, and, if needed, adjustments will be made in the next phase of testing.

Similarly, for the alternative disposition path for LAW Recycle, the composition will depend on the LAW waste and the status of coupled operations with diverted LAW Recycle. This conservative realistic case would also use the composition from fully coupled operations since that would have the highest concentration of problematic components. Processing during fully coupled operations is beneficial by eliminating this stream from the WTP system, which simplifies system integration and reduces the LAW glass volume. A future phase of this work will examine variability of the composition of the LAW melter feed.

Disposal of the adsorbent/precipitate stream from the radionuclide removal process is currently undefined. At this phase of development, the testing scope will attempt to quantify the amount and composition of slurry solids generated candidate processes. This information will be used in the future to determine the compatibility with the various disposal options. In this phase, the target adsorbents and precipitating agents will only include materials expected to be compatible with likely disposal pathways, with the focus on inorganic materials. Testing will also evaluate the precipitation/adsorption of components in the LAW Recycle that may impact disposal processes and requirements, such as co-precipitation of hazardous constituents (e.g., chromium).

\subsection{TECHNOLOGY DEVELOPMENT}

The focus of this task will be to utilize existing technologies to provide solutions to disposition of this unique waste stream, enabling a quick resolution and path forward. Simulant formulation for various radioactive wastes has been performed many times, although it is generally performed on already existing streams that can be analyzed. The absence of concrete compositional data for the stream will make formulation more challenging, but will be addressed by using experienced judgment on components that may impact performance and selecting a conservative approach. Subsequent testing will involve variability testing, decreasing the technical risk of this uncertainty. Adsorption/precipitation testing will rely on existing materials, where feasible, and identify process options. Process flowsheet parameters will be based on currently existing facilities, such as HLW evaporators and the SRS ARP, which allows use of lessons learned and institutional knowledge to decrease technical uncertainty and risk.

\subsection{Simulant Formulation}

There are two primary inputs that can be used to develop the composition of the liquid and solid phases that will exist in the LAW Recycle: (1) the modeled compositions from the Hanford 
HTWOS flowsheet and (2) testing at pilot-scale for a number of different Hanford simulated wastes [Abramowitz, 2012]. This subtask will assemble those data and formulate an average expected aqueous composition, based heavily on the HTWOS model. The expected composition will be examined with a thermodynamic equilibrium chemistry model such as Geochemist Workbench or ESP (OLI Systems, Inc.) to examine thermodynamic stability and scaling potential. Since it has been observed that there are species in the LAW Recycle stream obtained from pilot-scale melter testing that were not in the original LAW feed, it is evident that some glass formers are carried overhead, partially dissolving in the aqueous stream. This step will be replicated in the laboratory to examine dissolution behavior and insoluble solids behavior. The simulant sample will be prepared on a one-liter scale, and analyzed and compared to model predictions. The simulant stability will be examined for a period of time ( 30 days) to determine whether additional composition changes (i.e., precipitation of solids) occur due to chemical instability. If this approach does not produce a simulant that approaches the expected range of compositions, further additions of soluble forms of the chemicals may be pursued. Depending on the variability and range of components identified, additional simulants may be developed in the future phases as well, and will rely more on modeling calculations to evaluate variability.

Spiking the simulant with radiotracers will be performed using those isotopes expected to be present in significant quantities, based on the Hanford HTWOS model for System Plan 7.4 with full coupled operations in WTP. Some radionuclides will be at the predicted concentration, but some may be lower to allow use of radiotracers for improved analytical accuracy and precision. It is possible that the some of the sparingly soluble radionuclides will not be present in the quantities predicted by the HTWOS model because that model does not account for chemical speciation or solubility. After radioactive spiking and allowing the solution to mix for a period of time to approach equilibrium, the simulant will be filtered to ensure that only soluble radionuclide levels are being investigated, since the inclusion of insoluble radionuclides in the simulant may skew the results to indicate a higher decontamination factor than is actually achievable with the adsorbents/agents.

For some tests, the simulated insoluble solids in the LAW Recycle stream will also need to be prepared. This would be important for both the future solid-liquid separation tests, as well as examining if any of these insoluble solids dissolve under various conditions. For example, this dissolution could impact evaporator scaling due to caustic dissolution of silica, as well as whether the waste remains within tank corrosion control limits if solids dissolve. The insoluble solids are believed to be largely glass formers that aerosolize in the melter cold cap or feed system and become captured in the scrubber. For this phase of the program, the insoluble solids will be created using glass formers used for the LAW melter system, with the quantity based on composition analysis results from testing on the DM1200 melter at Vitreous State Laboratory [Matlack, 2006].

\subsection{Law Recycle Simulant Blending}

This subtask will examine the chemical stability of mixtures of Hanford tank waste simulants with the SBS-WESP including thermodynamic modeling and mixing at ambient and elevated temperature. Non-radioactive simulants will be used initially for this task because the presence of radionuclides is not expected to affect the bulk chemical properties being investigated. The focus will be to evaluate if the unusually high concentration of anions such as fluoride and 
sulfate cause formation of intractable solids that impact subsequent processes, or if silicon and other glass-formers cause evaporator scale.

The LAW Recycle is assumed to be sent to tank AW-102, which is the feed tank for the 242-A evaporator, and the simulant will only be adjusted for tank corrosion control prior to evaporation. To remain within corrosion control limits, caustic and nitrite will need to be added to the simulant prior to blending, and allowed to mix with the simulant for several days to reach equilibrium. The quantity of caustic and nitrite added will be governed by Table 3-10 in HNFSD-WM-OCD-015, Rev. 29 [Jo, 2013], and will be adjusted to account for consumption of caustic by the loss of ammonia at the high $\mathrm{pH}$. There is not a specific limit for halide content in the evaporator compatibility limits, so testing will examine concentrating the simulant until appreciable (5 wt\%) solids are predicted to form.

Computer modeling will be used to calculate the maximum concentration that could be achieved by evaporation of the simulant before scaling is predicted to occur in the 242-A evaporator. This concentrated version of the simulant will be prepared as well, and utilized for blending studies to examine if the evaporator bottoms would be expected to form intractable solids when blended with tank wastes. The concentrated Recycle simulant will be blended with simulant of tank AW101, as an example of a potential receipt tank for the 242-A evaporator bottoms. Many other tanks are potential receipt tanks as well, and tank waste compatibility assessment calculations will be performed in the next phase of this program to examine options.

\subsection{Ion Exchange/Adsorption}

As an alternative disposition by processing in the ETF, certain radionuclides may need to be removed from the LAW Recycle stream to meet the waste acceptance criteria for ETF. The waste acceptance criteria for receipt directly into the STT has not been developed. This evaporator is currently run to 20-40 wt\% solids in the bottoms, and the STU conceptual design typically used a $30 \mathrm{wt} \%$ total dissolved solids simulant [RPP-RPT-50967]. For this R\&D plan, the waste acceptance criteria will be developed based on the concentration of the LAW Recycle at which solids are predicted to form at ambient temperature (see task above for generation of concentrated simulant). There may be some tolerance for insoluble solids in the STU process, and this will be evaluated if they appear before reaching $30 \mathrm{wt} \%$ dissolved solids. This will yield a "concentration factor" for the LAW Recycle. The allowable levels of radionuclide contaminants in that concentrated liquid will then be limited by the following three criteria: disposal criteria for IDF, dose rate at ETF, and LERF source term limits. The disposal criteria for the solidified waste in the IDF must meet (a) $<100 \mathrm{nCi} / \mathrm{g}$ TRU, and (b) < Class C levels.

The ETF ${ }^{137} \mathrm{Cs}$ limit is based on the dose rate used for calculation of the shielding requirements for the STU, which was 1E-6 Ci/L [HNF-26914, Appendix H]. The LERF source term limits include certain radionuclides [Halgren, 2012], but more may need to be evaluated to ensure the facility inventory remains less than Category 3. The concentration factor calculated in the task above will be applied to the first two limits to obtain the influent acceptance criteria for the ETF. The LERF limits, will be applied directly to the acceptance criteria without any concentration factors. Whichever radionuclide limit of the three criteria is lowest will be used to obtain an overall target waste acceptance limit. Appendix A contains an estimate of the target DF required for those species with specific limits. As mentioned above, an achievable DF will also be 
determined, based on experimentation that shows the DF that can be achieved with available technology. (Several assumptions have been made in this document about the acceptability of radionuclide decontamination and potential waste forms for disposal. These assumptions have been used to define acceptability criteria for feasibility studies on removal. These limits are not intended to define regulatory or facility limits, but rather provide a starting point for evaluating various technologies.)

\subsubsection{Technetium}

The primary removal process investigated for technetium removal will be reductive precipitation coupled with adsorption (see below). If these are unsuccessful, a number of organic ionexchange media (e.g., Purolite ${ }^{\circledR}$ A530E) will be evaluated against the target removal criterion to identify which media are appropriate. Selected materials will be used in batch contacts with simulant at laboratory scale to determine their affinity for technetium. Where the experimental measurements indicate the potential for successful deployment, additional testing will be carried out to measure adsorption isotherms and kinetics.

\subsubsection{Actinides}

Initially, actinide removal will be examined using MST and mMST [Hobbs, 2008]. MST is currently used at SRS for removing ${ }^{90} \mathrm{Sr}$ and actinides from tank waste (comparable to LAW feed). The mMST has been developed and is a deployable technology, exhibiting faster and more effective removal efficiencies. Both are used in a batch-contact mode, where the solids are added to the liquid, agitated for a period of time, and removed by filtration. Testing will be performed using a range of concentrations of mMST and MST, and the rate of adsorption will be measured.

\subsection{3 $\underline{\text { Strontium }}$}

Similar to the actinides, initial removal of strontium will be examined using MST and mMST [Hobbs, 2008]. As mentioned above, MST is currently used at SRS for removing ${ }^{90} \mathrm{Sr}$ and actinides from tank waste and the mMST has been developed and is a deployable technology, exhibiting faster and more effective removal efficiencies. Additionally, a commercial zeolite will also be selected for testing (e.g. Ionsiv ${ }^{\circledR}$ R9510, sodium nonatitanate). Testing will be performed using a range of concentrations of adsorbents, and the kinetics of adsorption will be measured.

\subsubsection{Cesium}

Cesium removal will initially be examined using commercially available aluminosilicate zeolites (e.g. Ionsiv ${ }^{\circledR}$ R9150/60). Zeolites have been used for decades at Hanford and Savannah River for removal of ${ }^{137} \mathrm{Cs}$ from low ionic strength streams, such as evaporator condensates. In this application, the zeolite will be used in a batch-contact mode, where the solids are added to the liquid, agitated for a period of time, and removed by settling or coarse filtration. It is possible that ammonium ion will interfere with absorption of ${ }^{137} \mathrm{Cs}$ in this waste stream. Additional testing will also be performed using a crystalline silicotitanate (CST) zeolite that has a very high affinity for cesium. Testing may also include $\mathrm{pH}$ adjustment to convert the interfering ammonium ion to neutral ammonia. Testing will be performed using a range of concentrations of adsorbents, and the rate of adsorption will be measured. 


\subsubsection{Iodine}

Current technologies for removal of iodine by absorption onto a solid are expected to be challenged by the presence of large concentrations of other halides projected to be present in the LAW Recycle. Since the ETF is already equipped for capture of iodine, and this has been initially addressed [Lueck, 2008], the impact of increased ${ }^{129}$ I concentration will be evaluated in this phase by calculations and comparison with current capabilities and limits. The evaluation will examine distribution of iodine in the evaporator, capture in the off-gas system, and facility impacts. Depending on results of the evaluation, testing may be identified for future phases.

\subsection{Precipitation}

A reductive precipitation/adsorption process will be investigated for removing ${ }^{99} \mathrm{Tc}$. Testing will examine the effectiveness of a number of precipitation agents (e.g. Sn(II)/ISMIO, Sn(II) hydroxyapatite [Mattigod, 2003], Sn(II)/oxalate, and Blast Furnace Slag (BFS)). Testing will be performed using a range of concentrations of agent concentrations, and the precipitation rate will be measured. Formulations that yield good ${ }^{99} \mathrm{Tc}$ removal will be followed up with testing to examine the re-dissolution of ${ }^{99} \mathrm{Tc}$ due to oxidation. Depending on results with the sorption technologies, additional methods for removal of actinides may also be tested, such as coprecipitation with iron or manganese.

In the next phase, testing will also examine solid-liquid separation technologies including settledecant and various filtration methods, such as cartridge, cross-flow, or rotary microfiltration.

\subsection{Concentration}

Another option is to decontaminate the LAW Recycle prior to sending it to ETF by concentration, either using evaporation or reverse osmosis. The decontaminated stream (condensed overheads from evaporator or permeate from reverse osmosis) would be sent to ETF and the concentrated stream to either the Tank Farms or recycled to the LAW Melter. Both of these concentration processes need to be tested to determine key operating parameters and potential impacts on those facilities.

Testing for evaporation in this phase will focus on solids formation and foaming. Evaporation of the SBS/WESP simulant in this phase will be performed with standard laboratory equipment using two versions of the simulant; one will be pre-adjusted for corrosion control, and one will not. Both simulants will be pre-contacted with the insoluble solids simulant generated from glass formers, and then decanted prior to evaporation. The simulant will be evaporated to 2-3 concentrations, and allowed to cool to room temperature to examine for insoluble solids formation and characterization. The final target concentration will be a specific gravity of 1.43 $\mathrm{g} / \mathrm{mL}$ [Belsher, 2012, section 5.3.4], but this may not be achievable due to insoluble solids formation. The concentrated liquid will be allowed to cool to room temperature and examined for insoluble solids formation. Any insoluble solids formed will be isolated and analyzed to determine the solids quantity, density and elemental composition as well as identifying the crystalline phases present in the solids. The characterization results for the insoluble solids will be evaluated versus those parameters important for transfer of radioactive slurries. If the solids are $>5 \mathrm{wt} \%$ and have a specific gravity of $>1.35 \mathrm{~g} / \mathrm{cc}$, additional evaluations related to tank farm transfer capabilities are needed [Jo, 2013, section 3.5.1]. Evaporation tests will also target lower 
concentration levels, based on computer modeling predictions, where insoluble solids are predicted to just begin to form. Preventing insoluble solids formation will avoid having to manage additional solids in the system. It is expected that testing to this range of concentrations will cover both evaporation in the 242-A evaporator, and in the ETF or an auxiliary evaporator. Since these evaporators run at very different pressures and temperatures, some testing will be done under both vacuum and atmospheric pressures, but will not fully mimic scaling tendency on metallic evaporator surfaces. Future testing phases will examine deposition of scale on steel evaporator components if aluminosilicate solids are identified in preliminary tests.

To evaluate if RO treatment is a plausible method for concentration and disposition of this stream, several sources of information will be developed and/or obtained, including the ETF acceptance criteria calculated in task 2.3 above, calculation of osmotic pressure and viable concentration factor, and observations of insoluble solids formation obtained from evaporative concentration testing to determine if RO is also plausible. If use of an RO is found plausible, non-radioactive testing will be performed in this phase, and will examine fouling and achievable concentration factors. Measuring the DF of radionuclides will be done with non-radioactive isotopes/surrogates spiked at higher concentrations to obtain an estimate of performance for minimal cost. This approach is adequate at this stage, since the DF of an RO membrane is not strongly dependent on the concentration of the species that are well below their solubility limit, only its ionic size and charge. Testing of various pre-filtration methods will be performed in the next phase, if RO is selected as a concentration method. Measuring the DF of radioactive constituents will be performed in subsequent phases of this program, if RO is shown to have substantial benefits in the preliminary tests.

\subsection{CONCLUSIONS}

This task will provide the initial data to establish plausible disposal options for the SBS/WESP LAW Recycle stream. Testing will examine compatibility of the stream with existing process infrastructure, as well as alternative options. The complex waste treatment system is highly integrated, but potential solutions have been developed that may enable substantial reductions in cost, schedule, and operational challenges of the Hanford WTP. These postulated solutions may have short-term benefits of avoiding return of wastes to the tank farm and improving WTP throughput, as well as long-term benefits to the clean-up mission by reduction in the LAW glass volume and mission duration.

This phase of the program will examine the initial feasibility of the potential disposition paths for the LAW Recycle. (The scope defined in these phases is based on technical information needed to reach a decision point about feasibility and developing a path forward, and is not based on budget or schedule.) This testing will examine

- initial simulant formulation (one composition),

- concentration of Recycle using a laboratory-scale evaporator; to simulate either in 242-A or an auxiliary evaporator; evaluate formation of solids; and potentially non-radioactive reverse osmosis,

- blending of Recycle and concentrated Recycle with tank waste, and 
- precipitation $\left({ }^{99} \mathrm{Tc}\right)$ and absorption of radionuclides $\left({ }^{90} \mathrm{Sr},{ }^{137} \mathrm{Cs}\right.$, actinides); initial examination of achievable DF and estimates of slurry volume; down-select of preferred technology; solid slurry behavior.

The fate of ${ }^{129}$ I in ETF will also be evaluated, based on currently available information.

The next phase of the program will further develop these concepts and disposition paths. This phase will examine

- LAW Recycle composition variability impacts,

- concentration in scaled mock-up equipment,

- adsorption/precipitation optimization, scale-up, and variability,

- solid-liquid separation,

- slurry rheology, stability, and settling behavior,

- corrosion testing,

- impact of insoluble solids from LAW Recycle in HLW storage tanks,

- slurry disposition routes and compatibility,

- impact of LAW Recycle processing on ETF STU throughput, composition, and RCRA compliance,

- radioactive reverse osmosis membrane testing, and

- potential for formation of solids in LERF from blended streams.

Future phases of the program will mature these concepts and test disposition paths and will likely include

- solid-liquid separation scale-up,

- process scale-up

- composition variability testing

- corrosion mitigation

- slurry blending, storage, and immobilization, and

- testing of immobilization of LAW Recycle in the ETF Solidification Treatment Unit. 
SRNL-STI-2013-00351, Rev. 0

\subsection{REFERENCES}

Abramowitz, H., Brandys, M., Cecil, R., D’Angelo, N., Matlack, K.S., Muller, I.S., Pegg, I.L., Callow, R.A., Joseph, I., Technetium Retention in WTP LAW Glass with Recycle Flow-Sheet: DM10 Melter Testing, VSL-12R2640-1, Rev. 0, RPP-54130, September, 2012.

Arakali, V., Stone, I., 2012 WTP Tank Utilization Assessment, 24590-WTP-RPT-PE-12-001, Rev. 0, March 26, 2012

Belsher, J.D., Empey, P.A., Hohl, T.M., Kirkbride, R.A., Ritari, J.S., West, E.B., Bergmann, L., M., Wells, M.N., Hanford Tank Waste Operations Simulator (HTWOS) Version 7.4 Model Design Document, RPP-17152, Rev. 7, November, 2012

Crawford, T.W., Conner, J.M., Johnson, M.E., Mann, F.M., Unterreiner, B.J., Williamson, R.D., Lueck, K.J., McNamar, E.A., Secondary Waste Management Strategy for Early Low Activity Waste Treatment, RPP-RPT-37924, July, 2008.

Edgemon, G.L., Anda, V.S., Dahl, M.M., Piekarski, C.M., Corrosion Assessment of Effluent Treatment Facility (ETF) for Secondary Liquid Waste Treatment (SLWT) Project, RPP-50821, September, 2012

Halgren, D.L., Liquid Waste Processing Facilities Waste Acceptance Criteria, HNF-3172, Rev. 6, October, 2012

Hobbs, D.T., Improved Strontium and Actinide Separations Modified Monosodium Titanate Final Report of FY2008 Testing Activities, SRNL-STI-2008-00390, December, 2008.

Icenhower, J.P., Qafoku, N.P., Martin, W.J., Zachara, J.M., The Geochemistry of Technetium: A Summary of the Behavior of an Artificial Element in the Natural Environment, PNNL-18139, December 2008

Icenhower, J.P., Qafoku, N.P., Martin, W.J., Zachara, J.M., The Biogeochemistry of Technetium: A review of the behavior of an Element in the Natural Environment, October 2010

Jo, J., Tank Farms Waste Transfer Compatibility Program, HNF-SD-WM-OCD-015, Rev. 29, March, 2013

Lueck, K.J., Mcnamar, E.A., Low Activity Waste (LAW) Facility Secondary Waste to Effluent Treatment Facility (ETF) Treatability Evaluation, HNF-37718, May, 2008

Mann, F.M., Puigh, R.J., Khaleel, R., Finfrock, S., McGrail, B.P., Bacon, D.H., Serne, R.J., Risk Assessment Supporting the Decision on the Initial Selection of Supplemental ILAW Technologies, RPP-17675, Rev. 0, September 29, 2003 
Matlack, K.S., Gong, W., Diener, G., Bardakci, T., Brandys, M., Pegg, I.L., Final Report; Summary of DM1200 SBS History and Performance, VSL-06R6410-2, August, 2, 2006

Mattigod, S.V., Serne, R.J., Fryxell, G.E., Selection and Testing of "Getters" for Adsorption of Iodine-129 and Technetium-99: A Review, PNNL-14208, September, 2003

May, T.H., Gehner, P.D., Stegen, G., Hymas, J., Pajunen, A., Sexton, R., Ramsey, A., Secondary Waste - ETF Pre-Conceptual Engineering Study, RPP-RPT-43588, December 22, 2009

RPP-RPT-50967, Secondary Liquid Waste Treatment Project (T3W08) Conceptual Design Report

Wilmarth, W.R., McCabe, D.J., Nash, C.A., Task Technical and Quality Assurance Plan for Developing a Flowsheet for Off-Gas Process Liquids from the Hanford Low Activity Waste Vitrification Process, SRNL-RP-2013-00135, March, 2013

Yanochko, R.M., Corcoran, C., Golcar, G.R., Johnson, P., Nolan, L.M., Pajunen, A., Submerged Bed Scrubber Condensate Disposal Preconceptual Engineering Study, RPP-RPT-52321, September, 2012

SVF-2732, 2013, “SVF-2732 MMR-13-008 data Case 1 rev 0.xlsx,” Rev. 0, Washington River Protection Solutions, LLC, Richland, Washington. 
SRNL-STI-2013-00351, Rev. 0

\subsection{ATTACHMENTS}

Appendix A contains a preliminary estimate of the SBS/WESP LAW Recycle stream composition [SVF-2732] based on System Plan 7.4, and the calculated DF required for receipt at ETF. The calculated DF is based on the three criteria listed in Section 2.3, and adjusted for an estimated concentration factor of 16X. The concentration factor of $16 \mathrm{X}$ is based on the sum of the halide concentrations in the Recycle ( $1.45 \mathrm{~g} / \mathrm{L}$ fluoride; $0.95 \mathrm{~g} / \mathrm{L}$ chloride), and concentrated to $40,000 \mathrm{ppm}$ total halide. The $40,000 \mathrm{ppm}$ total halide is an estimate of the corrosion limit expected at ETF [Lueck, 2008], but may exceed the allowable concentration factor for the ETF STU due to formation of insoluble solids. This calculated DF requirement should be viewed as an approximation to be used for test planning. This does not include the achievable DF target, and therefore does not account for impacts on the IDF PA.

The Minimum, Maximum, and Average concentration columns are calculated based on the reference [SVF-2732], which was a special HTWOS model run for System Plan 7.4. The next column to the right is the TRU limit for the waste form, and ${ }^{137} \mathrm{Cs}$ dose limit for ETF. The next column to the right divides those values by $16 \mathrm{X}$, the concentration factor. Similarly, the Class $\mathrm{C}$ limit for the waste form, and concentration adjusted columns are next. The LERF limit is shown without any concentration adjustment. The Bounding-limit column shows the lowest of those values. None of these account for the volumetric dilution expected from immobilizing the liquid in the ETF STU. Similarly, the TRU limits are defined as a weight basis $(100 \mathrm{Ci} / \mathrm{g})$, and this calculation conservatively assumes a density of $1.0 \mathrm{~g} / \mathrm{mL}$ to convert to volumetric concentration.

The calculation for the target DF was based on the average concentration. If the average concentration is beneath the limit, the DF is "NA" or not applicable. Some species have an average feed concentration that is beneath the limit, but the maximum concentration is above the limit. These species are identified as "NA*".

Calculations for this appendix are contained in SRNL-NB-2013-00060. 


\section{Appendix A. SBS/WESP LAW Composition and DF Calculation Results}

SRNL-STI-2013-00351, Rev. 0

\begin{tabular}{|c|c|c|c|c|c|c|c|c|c|c|c|}
\hline Constituent & Units & Maximum & Minimum & Average & $\begin{array}{l}\text { TRU limit/Cs } \\
137 \text { dose } \\
\text { limit }\end{array}$ & $\begin{array}{l}\text { TRU/dose } \\
\text { concentr. } \\
\text { adjusted } \\
(16 \mathrm{X}) \\
\end{array}$ & Class C & $\begin{array}{l}\text { Class C } \\
\text { conc. } \\
\text { adjusted } \\
(16 \mathrm{X}) \\
\end{array}$ & LERF & $\begin{array}{l}\text { Bounding Limit } \\
(\mathrm{Ci} / \mathrm{L})\end{array}$ & $\begin{array}{c}\text { DF } \\
\text { required }\end{array}$ \\
\hline $106 \mathrm{Ru}$ & $\mathrm{Ci} / \mathrm{L}$ & $1.87 \mathrm{E}-09$ & $3.17 \mathrm{E}-13$ & $3.53 \mathrm{E}-10$ & & & & & $6.50 \mathrm{E}-07$ & \begin{tabular}{|r|}
$6.50 \mathrm{E}-07$ \\
\end{tabular} & $\mathrm{NA}$ \\
\hline $113 \mathrm{mCd}$ & $\mathrm{Ci} / \mathrm{L}$ & $1.16 \mathrm{E}-07$ & $1.44 \mathrm{E}-08$ & $4.90 \mathrm{E}-08$ & & & & & & & \\
\hline${ }_{125} \mathrm{Sb}$ & $\mathrm{Ci} / \mathrm{L}$ & $5.56 \mathrm{E}-06$ & 1.90E-08 & $1.12 \mathrm{E}-06$ & & & & & & & \\
\hline $126 \mathrm{Sn}$ & $\mathrm{Ci} / \mathrm{L}$ & $1.91 \mathrm{E}-08$ & $6.55 \mathrm{E}-10$ & $6.22 \mathrm{E}-09$ & & & & & & & \\
\hline $129 \mathrm{I}$ & $\mathrm{Ci} / \mathrm{L}$ & $5.01 E-08$ & $9.41 \mathrm{E}-09$ & $2.58 \mathrm{E}-08$ & & & $8.00 \mathrm{E}-05$ & $5.00 \mathrm{E}-06$ & $1.80 \mathrm{E}-06$ & $1.80 \mathrm{E}-06$ & NA \\
\hline $134 \mathrm{Cs}$ & $\mathrm{Ci} / \mathrm{L}$ & $5.17 \mathrm{E}-10$ & $1.62 \mathrm{E}-12$ & $9.61 \mathrm{E}-11$ & & & & & $4.10 \mathrm{E}-07$ & $4.10 \mathrm{E}-07$ & NA \\
\hline $137 \mathrm{Cs}$ & $\mathrm{Ci} / \mathrm{L}$ & $1.16 \mathrm{E}-05$ & $1.80 \mathrm{E}-06$ & $5.21 \mathrm{E}-06$ & $1.00 \mathrm{E}-06$ & $6.25 \mathrm{E}-08$ & & & $1.00 \mathrm{E}-05$ & $6.25 \mathrm{E}-08$ & 83 \\
\hline $137 \mathrm{mBa}$ & $\mathrm{Ci} / \mathrm{L}$ & $1.09 \mathrm{E}-05$ & $1.70 \mathrm{E}-06$ & $4.92 \mathrm{E}-06$ & & & & & & & \\
\hline${ }_{14} \mathrm{C}$ & $\mathrm{Ci} / \mathrm{L}$ & $0.00 \mathrm{E}+00$ & $0.00 \mathrm{E}+00$ & $0.00 \mathrm{E}+00$ & & & $8.00 \mathrm{E}-03$ & $5.00 \mathrm{E}-04$ & $1.60 \mathrm{E}-06$ & $1.60 \mathrm{E}-06$ & NA \\
\hline $151 \mathrm{Sm}$ & $\mathrm{Ci} / \mathrm{L}$ & 2.67E-05 & $3.75 E-07$ & $8.66 \mathrm{E}-06$ & & & & & & & \\
\hline $152 \mathrm{Eu}$ & $\mathrm{Ci} / \mathrm{L}$ & $5.53 \mathrm{E}-09$ & $4.32 \mathrm{E}-11$ & 1.63E-09 & & & & & & & \\
\hline $154 \mathrm{Eu}$ & $\mathrm{Ci} / \mathrm{L}$ & $1.86 \mathrm{E}-07$ & $3.11 \mathrm{E}-09$ & $4.50 \mathrm{E}-08$ & & & & & $9.80 \mathrm{E}-06$ & $9.80 E-06$ & NA \\
\hline $155 \mathrm{Eu}$ & $\mathrm{Ci} / \mathrm{L}$ & $9.64 \mathrm{E}-08$ & $1.12 \mathrm{E}-09$ & $2.42 \mathrm{E}-08$ & & & & & $6.30 \mathrm{E}-05$ & $6.30 \mathrm{E}-05$ & NA \\
\hline $226 \mathrm{Ra}$ & $\mathrm{Ci} / \mathrm{L}$ & $8.56 \mathrm{E}-12$ & $7.26 \mathrm{E}-13$ & $3.53 \mathrm{E}-12$ & & & & & $6.40 \mathrm{E}-08$ & $6.40 \mathrm{E}-08$ & NA \\
\hline $227 \mathrm{Ac}$ & $\mathrm{Ci} / \mathrm{L}$ & $3.64 \mathrm{E}-11$ & $-1.11 \mathrm{E}-10$ & $2.63 \mathrm{E}-12$ & & & & & & & \\
\hline $228 \mathrm{Ra}$ & $\mathrm{Ci} / \mathrm{L}$ & $1.47 \mathrm{E}-08$ & $3.03 \mathrm{E}-10$ & $3.85 \mathrm{E}-09$ & & & & & & & \\
\hline $229 \mathrm{Th}$ & $\mathrm{Ci} / \mathrm{L}$ & $1.05 \mathrm{E}-11$ & $6.50 \mathrm{E}-14$ & $2.40 \mathrm{E}-12$ & & & & & & & \\
\hline $231 \mathrm{~Pa}$ & $\mathrm{Ci} / \mathrm{L}$ & $2.03 \mathrm{E}-10$ & $7.25 \mathrm{E}-12$ & $4.68 \mathrm{E}-11$ & & & & & & & \\
\hline $232 \mathrm{Th}$ & $\mathrm{Ci} / \mathrm{L}$ & $2.44 \mathrm{E}-11$ & $2.24 \mathrm{E}-13$ & $5.18 \mathrm{E}-12$ & & & & & & & \\
\hline $232 \mathrm{U}$ & $\mathrm{Ci} / \mathrm{L}$ & $2.52 \mathrm{E}-11$ & $1.94 \mathrm{E}-12$ & $9.93 \mathrm{E}-12$ & & & & & $2.1 \mathrm{E}-10$ tot $\mathrm{U}$ & $2.1 \mathrm{E}-10$ tot $\mathrm{U}$ & 6 \\
\hline $233 \mathrm{U}$ & $\mathrm{Ci} / \mathrm{L}$ & $2.19 \mathrm{E}-09$ & $9.08 \mathrm{E}-11$ & $5.63 \mathrm{E}-10$ & & & & & $2.1 \mathrm{E}-10$ tot $\mathrm{U}$ & $2.1 \mathrm{E}-10$ tot $\mathrm{U}$ & 6 \\
\hline $234 \mathrm{U}$ & $\mathrm{Ci} / \mathrm{L}$ & $8.16 \mathrm{E}-10$ & $9.06 \mathrm{E}-11$ & $2.85 \mathrm{E}-10$ & & & & & $2.1 \mathrm{E}-10$ tot $\mathrm{U}$ & $2.1 \mathrm{E}-10$ tot $\mathrm{U}$ & 6 \\
\hline $235 \mathrm{U}$ & $\mathrm{Ci} / \mathrm{L}$ & $3.27 \mathrm{E}-11$ & $3.76 \mathrm{E}-12$ & $1.19 \mathrm{E}-11$ & & & & & $2.1 \mathrm{E}-10$ tot $\mathrm{U}$ & $2.1 \mathrm{E}-10$ tot $\mathrm{U}$ & 6 \\
\hline $236 \mathrm{U}$ & $\mathrm{Ci} / \mathrm{L}$ & $4.59 \mathrm{E}-11$ & $2.62 \mathrm{E}-12$ & $8.25 \mathrm{E}-12$ & & & & & $2.1 \mathrm{E}-10$ tot $\mathrm{U}$ & $2.1 \mathrm{E}-10$ tot $\mathrm{U}$ & 6 \\
\hline $237 \mathrm{~Np}$ & $\mathrm{Ci} / \mathrm{L}$ & $1.41 \mathrm{E}-09$ & $1.46 \mathrm{E}-10$ & $4.73 \mathrm{E}-10$ & $<1 \mathrm{E}-4$ total & $<6 \mathrm{E}-6$ total & $<1 \mathrm{E}-4$ total & $<6 \mathrm{E}-6$ total & $2.10 \mathrm{E}-09$ & $2.10 \mathrm{E}-09$ & NA \\
\hline $238 \mathrm{Pu}$ & $\mathrm{Ci} / \mathrm{L}$ & $3.58 \mathrm{E}-09$ & $5.94 \mathrm{E}-10$ & $1.68 \mathrm{E}-09$ & $<1 \mathrm{E}-4$ total & $<6 \mathrm{E}-6$ total & $<1 \mathrm{E}-4$ total & $<6 \mathrm{E}-6$ total & $2.80 \mathrm{E}-09$ & $2.80 \mathrm{E}-09$ & $\mathrm{NA}^{*}$ \\
\hline $238 \mathrm{U}$ & $\mathrm{Ci} / \mathrm{L}$ & $7.22 \mathrm{E}-10$ & $8.54 \mathrm{E}-11$ & $2.81 \mathrm{E}-10$ & & & & & $2.1 \mathrm{E}-10$ tot $\mathrm{U}$ & $2.10 \mathrm{E}-10$ & 6 \\
\hline${ }_{239} \mathrm{Pu}$ & $\mathrm{Ci} / \mathrm{L}$ & $5.67 \mathrm{E}-08$ & $7.55 \mathrm{E}-09$ & $3.13 E-08$ & $<1 \mathrm{E}-4$ total & $<6 \mathrm{E}-6$ total & $<1 \mathrm{E}-4$ total & $<6 \mathrm{E}-6$ total & 1.8E-8 Pu-239/240 & 1.8E-8 Pu-239/240 & 2 \\
\hline${ }_{240} \mathrm{Pu}$ & $\mathrm{Ci} / \mathrm{L}$ & $1.26 \mathrm{E}-08$ & $2.51 \mathrm{E}-09$ & $6.63 \mathrm{E}-09$ & $<1 \mathrm{E}-4$ total & $<6 \mathrm{E}-6$ total & $<1 \mathrm{E}-4$ total & $<6 \mathrm{E}-6$ total & 1.8E-8 Pu-239/240 & 1.8E-8 Pu-239/240 & 2 \\
\hline $241 \mathrm{Am}$ & $\mathrm{Ci} / \mathrm{L}$ & $1.50 \mathrm{E}-06$ & $2.14 \mathrm{E}-08$ & $2.32 \mathrm{E}-07$ & $<1 \mathrm{E}-4$ total & $<6 \mathrm{E}-6$ total & $<1 \mathrm{E}-4$ total & $<6 \mathrm{E}-6$ total & $1.40 \mathrm{E}-09$ & $1.40 \mathrm{E}-09$ & 166 \\
\hline${ }_{241} \mathrm{Pu}$ & $\mathrm{Ci} / \mathrm{L}$ & $1.49 \mathrm{E}-07$ & $2.01 \mathrm{E}-08$ & $5.51 E-08$ & & & 3.50E-03 & $2.19 \mathrm{E}-04$ & $2.60 \mathrm{E}-08$ & $2.60 \mathrm{E}-08$ & 2 \\
\hline $242 \mathrm{Cm}$ & $\mathrm{Ci} / \mathrm{L}$ & $8.75 \mathrm{E}-10$ & $6.38 \mathrm{E}-11$ & $3.43 \mathrm{E}-10$ & $<1 \mathrm{E}-4$ total & $<6 \mathrm{E}-6$ total & $2.00 \mathrm{E}-02$ & $1.25 \mathrm{E}-03$ & & $<6 \mathrm{E}-6$ total & NA \\
\hline${ }_{242} \mathrm{Pu}$ & $\mathrm{Ci} / \mathrm{L}$ & $1.14 \mathrm{E}-12$ & $1.95 \mathrm{E}-13$ & $4.93 E-13$ & $<1 \mathrm{E}-4$ total & $<6 \mathrm{E}-6$ total & $<1 \mathrm{E}-4$ total & $<6 \mathrm{E}-6$ total & & $<6 \mathrm{E}-6$ total & NA \\
\hline
\end{tabular}

Page A-1 
SRNL-STI-2013-00351, Rev. 0

\begin{tabular}{|c|c|c|c|c|c|c|c|c|c|c|c|}
\hline $243 \mathrm{Am}$ & $\mathrm{Ci} / \mathrm{L}$ & $7.85 \mathrm{E}-10$ & $9.64 \mathrm{E}-12$ & $1.19 \mathrm{E}-10$ & $<1 \mathrm{E}-4$ total & $<6 \mathrm{E}-6$ total & $<1 \mathrm{E}-4$ total & $<6 \mathrm{E}-6$ total & & $<6 \mathrm{E}-6$ total & NA \\
\hline $243 \mathrm{Cm}$ & $\mathrm{Ci} / \mathrm{L}$ & $1.50 \mathrm{E}-10$ & $4.79 \mathrm{E}-12$ & $3.05 \mathrm{E}-11$ & $<1 \mathrm{E}-4$ total & $<6 \mathrm{E}-6$ total & $<1 \mathrm{E}-4$ total & $<6 \mathrm{E}-6$ total & & $<6 \mathrm{E}-6$ total & NA \\
\hline $244 \mathrm{Cm}$ & $\mathrm{Ci} / \mathrm{L}$ & $3.35 \mathrm{E}-09$ & $1.05 \mathrm{E}-10$ & $6.71 \mathrm{E}-10$ & $<1 \mathrm{E}-4$ total & $<6 \mathrm{E}-6$ total & $<1 \mathrm{E}-4$ total & $<6 \mathrm{E}-6$ total & $2.50 \mathrm{E}-08$ & $2.50 \mathrm{E}-08$ & NA \\
\hline${ }_{3} \mathrm{H}$ & $\mathrm{Ci} / \mathrm{L}$ & $0.00 E+00$ & $0.00 \mathrm{E}+00$ & $0.00 \mathrm{E}+00$ & & & & & $2.40 \mathrm{E}-04$ & $2.40 \mathrm{E}-04$ & NA \\
\hline $59 \mathrm{Ni}$ & $\mathrm{Ci} / \mathrm{L}$ & $3.55 \mathrm{E}-08$ & $2.41 \mathrm{E}-09$ & $7.11 \mathrm{E}-09$ & & & & & & & \\
\hline $60 \mathrm{Co}$ & $\mathrm{Ci} / \mathrm{L}$ & $7.09 \mathrm{E}-08$ & $3.69 \mathrm{E}-09$ & $1.65 \mathrm{E}-08$ & & & & & $2.40 \mathrm{E}-06$ & $2.40 \mathrm{E}-06$ & NA \\
\hline${ }_{63} \mathrm{Ni}$ & $\mathrm{Ci} / \mathrm{L}$ & $2.45 \mathrm{E}-06$ & $2.16 \mathrm{E}-07$ & $5.99 \mathrm{E}-07$ & & & & & & & \\
\hline $79 \mathrm{Se}$ & $\mathrm{Ci} / \mathrm{L}$ & $1.49 \mathrm{E}-07$ & $3.55 \mathrm{E}-08$ & $9.10 \mathrm{E}-08$ & & & & & $1.50 \mathrm{E}-07$ & $1.50 \mathrm{E}-07$ & NA \\
\hline $90 \mathrm{Sr}$ & $\mathrm{Ci} / \mathrm{L}$ & $1.07 \mathrm{E}-04$ & $1.03 E-05$ & $2.61 \mathrm{E}-05$ & & & & & $4.20 \mathrm{E}-05$ & $4.20 \mathrm{E}-05$ & $\mathrm{NA}^{*}$ \\
\hline $90 \mathrm{Y}$ & $\mathrm{Ci} / \mathrm{L}$ & $1.07 \mathrm{E}-04$ & $1.03 \mathrm{E}-05$ & $2.61 \mathrm{E}-05$ & & & & & & & \\
\hline $93 \mathrm{Zr}$ & $\mathrm{Ci} / \mathrm{L}$ & $2.64 \mathrm{E}-09$ & $1.47 \mathrm{E}-10$ & $9.33 \mathrm{E}-10$ & & & & & & & \\
\hline $93 \mathrm{~m} \mathrm{Nb}$ & $\mathrm{Ci} / \mathrm{L}$ & $2.16 \mathrm{E}-07$ & 3.07E-08 & $1.05 \mathrm{E}-07$ & & & & & & & \\
\hline $99 \mathrm{Tc}$ & $\mathrm{Ci} / \mathrm{L}$ & $6.11 \mathrm{E}-05$ & $1.99 \mathrm{E}-05$ & $4.15 \mathrm{E}-05$ & & & $3.00 \mathrm{E}-03$ & $1.88 \mathrm{E}-04$ & $1.80 \mathrm{E}-05$ & $1.80 \mathrm{E}-05$ & 2 \\
\hline $\mathrm{Ag}+$ & $g / L$ & $3.95 \mathrm{E}-05$ & $6.43 \mathrm{E}-07$ & $1.46 \mathrm{E}-05$ & & & & & & & \\
\hline $\mathrm{Al}(\mathrm{OH})_{4}$ & $\mathrm{~g} / \mathrm{L}$ & $1.35 \mathrm{E}-01$ & $4.97 \mathrm{E}-02$ & $1.01 \mathrm{E}-01$ & & & & & & & \\
\hline $\mathrm{Al}+3$ & $\mathrm{~g} / \mathrm{L}$ & $0.00 E+00$ & $0.00 \mathrm{E}+00$ & $0.00 \mathrm{E}+00$ & & & & & & & \\
\hline Asts & $\mathrm{g} / \mathrm{L}$ & $1.73 \mathrm{E}-03$ & $3.87 \mathrm{E}-05$ & $6.98 \mathrm{E}-04$ & & & & & & & \\
\hline $\mathrm{B}+3$ & $\mathrm{~g} / \mathrm{L}$ & $1.03 \mathrm{E}-04$ & $2.83 \mathrm{E}-06$ & $4.22 \mathrm{E}-05$ & & & & & & & \\
\hline $\mathrm{Ba}+2$ & $\mathrm{~g} / \mathrm{L}$ & $1.39 \mathrm{E}-05$ & $5.83 \mathrm{E}-07$ & $6.20 \mathrm{E}-06$ & & & & & & & \\
\hline $\mathrm{Be}+2$ & $\mathrm{~g} / \mathrm{L}$ & $7.46 \mathrm{E}-06$ & $7.87 \mathrm{E}-08$ & $1.35 \mathrm{E}-06$ & & & & & & & \\
\hline $\mathrm{Bi}+3$ & $\mathrm{~g} / \mathrm{L}$ & $4.66 \mathrm{E}-04$ & $7.81 \mathrm{E}-05$ & $2.62 \mathrm{E}-04$ & & & & & & & \\
\hline $\mathrm{C}_{10} \mathrm{H}_{12} \mathrm{~N}_{2} \mathrm{O}_{8}-4$ & $\mathrm{~g} / \mathrm{L}$ & $0.00 E+00$ & $0.00 \mathrm{E}+00$ & $0.00 \mathrm{E}+00$ & & & & & & & \\
\hline $\mathrm{C}_{10} \mathrm{H}_{15} \mathrm{~N}_{2} \mathrm{O}_{7-3}$ & $\mathrm{~g} / \mathrm{L}$ & $0.00 E+00$ & $0.00 \mathrm{E}+00$ & $0.00 \mathrm{E}+00$ & & & & & & & \\
\hline $\mathrm{C}_{12} \mathrm{H}_{27} \mathrm{O}_{4} \mathrm{P}$ & $g / L$ & $0.00 E+00$ & $0.00 \mathrm{E}+00$ & $0.00 \mathrm{E}+00$ & & & & & & & \\
\hline $\mathrm{C}_{13} \mathrm{H}_{28}$ & $\mathrm{~g} / \mathrm{L}$ & $0.00 E+00$ & $0.00 \mathrm{E}+00$ & $0.00 \mathrm{E}+00$ & & & & & & & \\
\hline $\mathrm{C}_{2} \mathrm{Cl}_{4}$ & $\mathrm{~g} / \mathrm{L}$ & $0.00 \mathrm{E}+00$ & $0.00 \mathrm{E}+00$ & $0.00 \mathrm{E}+00$ & & & & & & & \\
\hline $\mathrm{C}_{2} \mathrm{H}_{3} \mathrm{O}_{2}-$ & $g / L$ & $0.00 E+00$ & $0.00 \mathrm{E}+00$ & $0.00 \mathrm{E}+00$ & & & & & & & \\
\hline $\mathrm{C}_{2} \mathrm{H}_{3} \mathrm{O}_{3}-$ & $g / L$ & $0.00 E+00$ & $0.00 E+00$ & $0.00 \mathrm{E}+00$ & & & & & & & \\
\hline $\mathrm{C}_{2} \mathrm{HCl}_{3}$ & $g / L$ & $0.00 E+00$ & $0.00 E+00$ & $0.00 \mathrm{E}+00$ & & & & & & & \\
\hline $\mathrm{C}_{2} \mathrm{O}_{42}$ & $g / L$ & $0.00 \mathrm{E}+00$ & $0.00 E+00$ & $0.00 \mathrm{E}+00$ & & & & & & & \\
\hline $\mathrm{C}_{3} \mathrm{H}_{6} \mathrm{O}$ & $\mathrm{g} / \mathrm{L}$ & $0.00 E+00$ & $0.00 E+00$ & $0.00 \mathrm{E}+00$ & & & & & & & \\
\hline $\mathrm{C}_{4} \mathrm{H}_{10} \mathrm{O}$ & $\mathrm{g} / \mathrm{L}$ & $0.00 \mathrm{E}+00$ & $0.00 \mathrm{E}+00$ & $0.00 \mathrm{E}+00$ & & & & & & & \\
\hline $\mathrm{C}_{4} \mathrm{H}_{3} \mathrm{O}$ & $g / L$ & $0.00 E+00$ & $0.00 E+00$ & $0.00 \mathrm{E}+00$ & & & & & & & \\
\hline $\mathrm{C}_{s} \mathrm{H}_{s} \mathrm{~N}$ & $g / L$ & $0.00 E+00$ & $0.00 E+00$ & $0.00 \mathrm{E}+00$ & & & & & & & \\
\hline $\mathrm{C}_{6} \mathrm{H}_{5} \mathrm{NO}_{2}$ & $\mathrm{~g} / \mathrm{L}$ & $0.00 E+00$ & $0.00 E+00$ & $0.00 \mathrm{E}+00$ & & & & & & & \\
\hline $\mathrm{C}_{6} \mathrm{H}_{5} \mathrm{O}_{7-3}$ & $g / L$ & $0.00 E+00$ & $0.00 \mathrm{E}+00$ & $0.00 \mathrm{E}+00$ & & & & & & & \\
\hline $\mathrm{C}_{6} \mathrm{H}_{6}$ & $\mathrm{~g} / \mathrm{L}$ & $0.00 \mathrm{E}+00$ & $0.00 E+00$ & $0.00 \mathrm{E}+00$ & & & & & & & \\
\hline $\mathrm{C}_{7} \mathrm{H}_{6} \mathrm{~N}_{2} \mathrm{O}_{4}$ & $g / L$ & $0.00 E+00$ & $0.00 E+00$ & $0.00 \mathrm{E}+00$ & & & & & & & \\
\hline
\end{tabular}

Page A-2 
SRNL-STI-2013-00351, Rev. 0

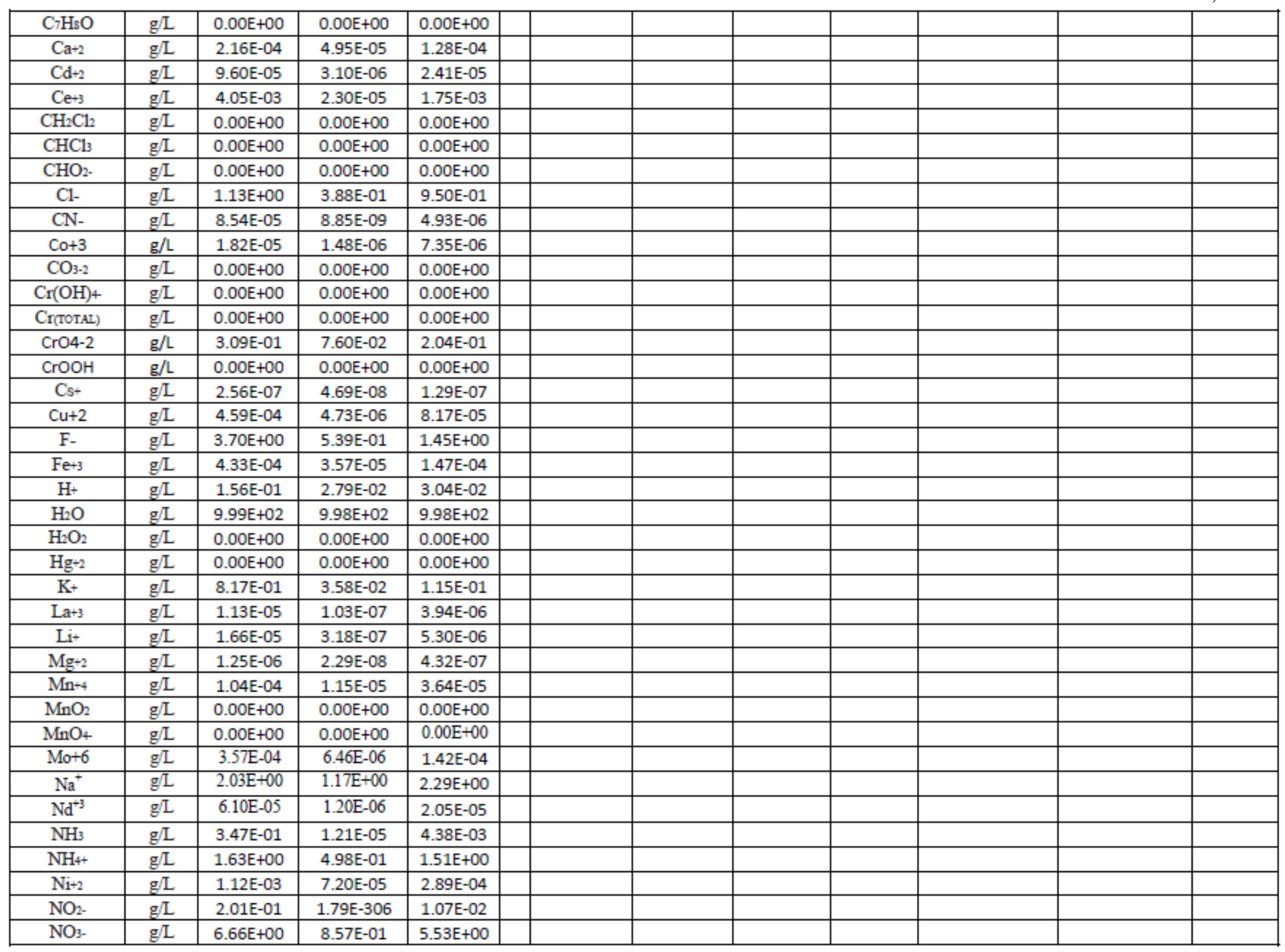

Page A-3 
SRNL-STI-2013-00351, Rev. 0

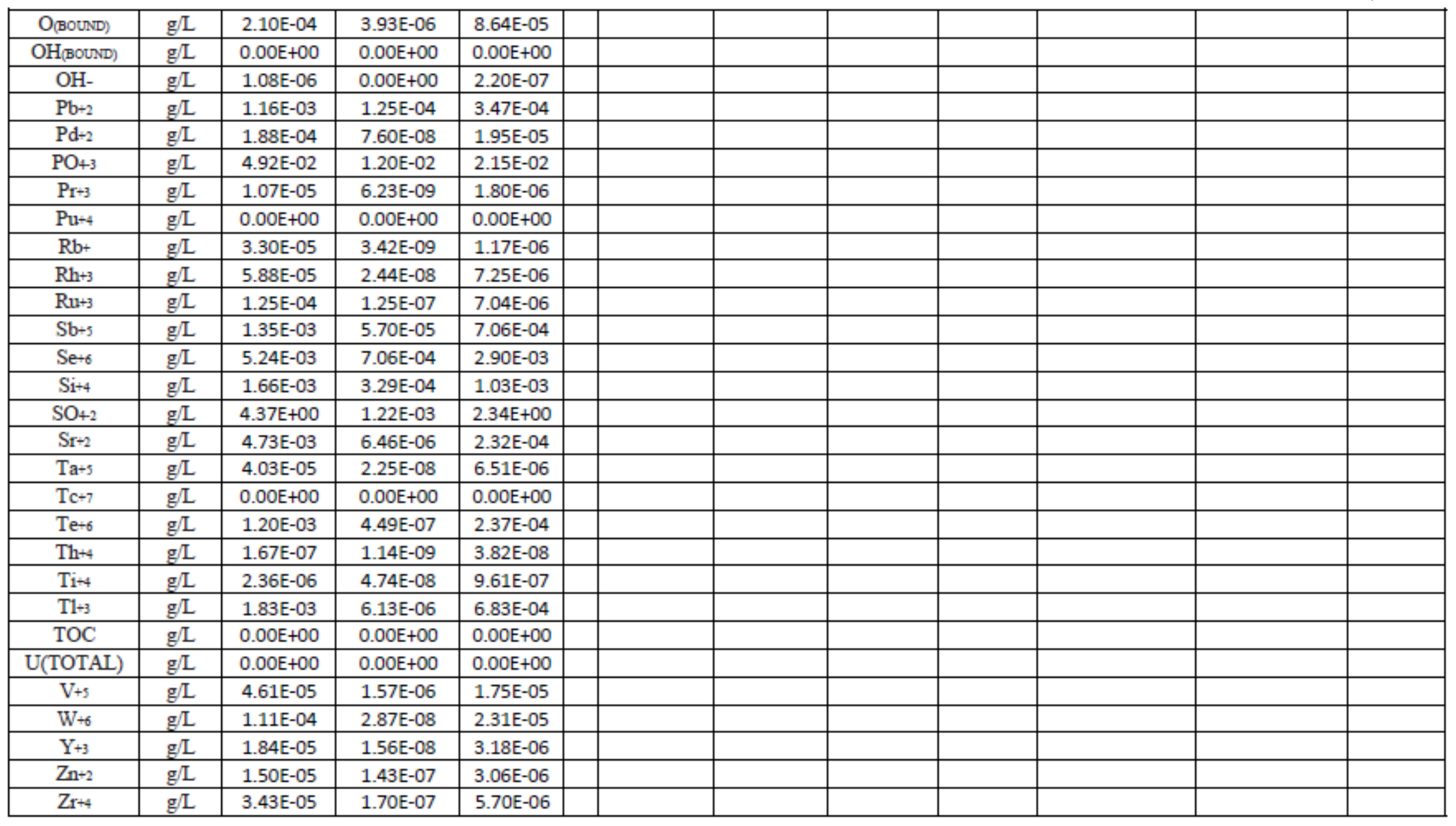

Page A-4 